\title{
1 Sorption mechanisms of lead on soil-derived black carbon formed under varying cultivation systems
}

3

4

5

6

$7{ }^{a}$ College of Tropical Crops, Hainan University, Haikou 570228, China

8 9 Chemical Engineering, Foshan University, Foshan 528000, China

${ }^{\mathrm{d}}$ Flood Control and Drought Relief Office of Hangjin County, Ordos 017400, China Hangzhou 311300, China

${ }^{*}$ Corresponding author. Foshan 528000, China

Qingjie Zhao ${ }^{\text {a,1 }}$, Jianhong Li ${ }^{\text {a,b,1, Binoy Sarkar }}{ }^{\text {c }}$, Weidong Wu a , Boling Li a ${ }^{\text {, Ruichun Liu }}{ }^{\text {d, Mohsin }}$ Nawaz $^{\text {e }}$, Muhammad Zia-ur-Rehman ${ }^{\text {f }}$, Hailong Wang ${ }^{\text {b,g,*** }}$, Zhipeng Wu ${ }^{\text {a,* }}$

${ }^{\mathrm{b}}$ Biochar Engineering Technology Research Center of Guangdong Province, School of Environmental and

${ }^{\mathrm{c}}$ Lancaster Environment Centre, Lancaster University, Lancaster, LA1 4YQ, United Kingdom

e Key Laboratory of Genetics and Germplasm Innovation of Tropical Special Forest Trees and Ornamental Plants, Ministry of Education, College of Forestry, Hainan University, Haikou 570228, China

${ }^{\mathrm{f}}$ Institute of Soil and Environmental Sciences, University of Agriculture, Faisalabad, 38040, Pakistan

g Key Laboratory of Soil Contamination Bioremediation of Zhejiang Province, Zhejiang A\&F University,

** Correspondence to: H. Wang, School of Environmental and Chemical Engineering, Foshan University,

E-mail addresses: hailong.wang@fosu.edu.cn (H. Wang), peter@hainanu.edu.cn (Z.Wu).

\footnotetext{
${ }^{1}$ Qingjie Zhao and Jianhong Li contributed to the work equally and should be considered co-first authors.
} 
25 Cultivation intensities of soils significantly affect black carbon characteristics.

26 High cultivation intensity increased $\mathrm{Pb}$ in ion exchange fraction on black carbon.

27 Ion exchange and hydrogen bonded $\mathrm{Pb}$ fractions accounted for about $80 \%$ of total $\mathrm{Pb}$.

\section{Graphical abstract}

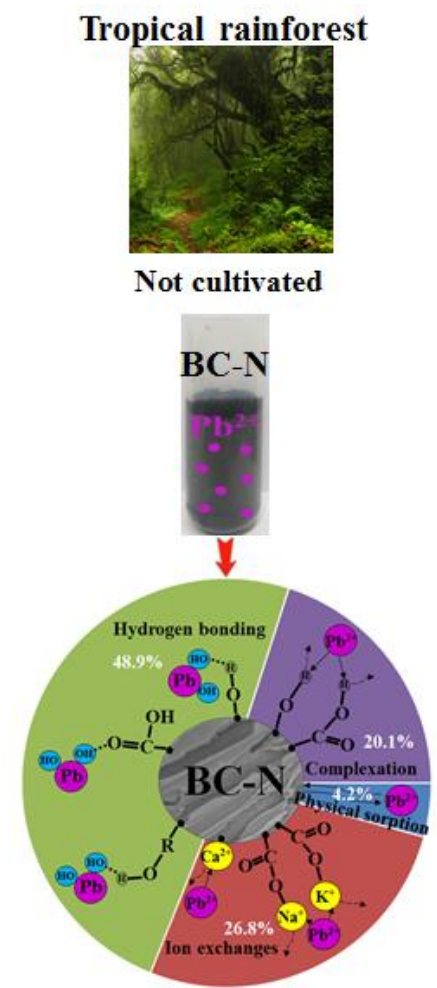

Control

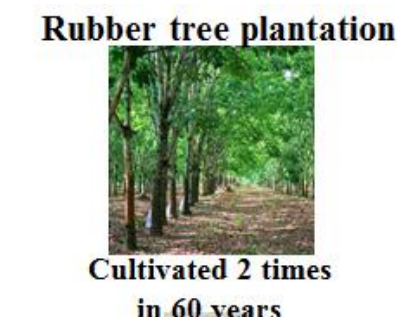

in 60 years

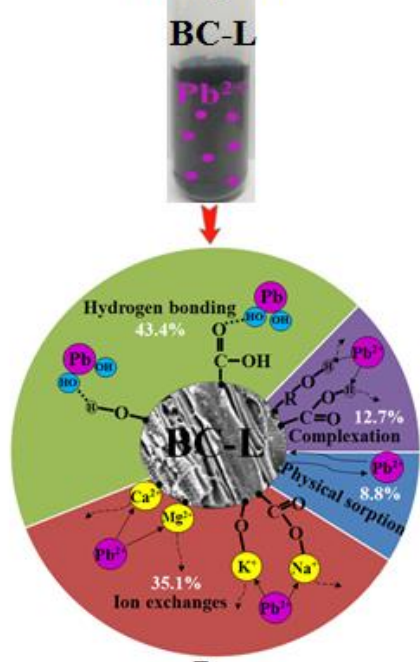

Low

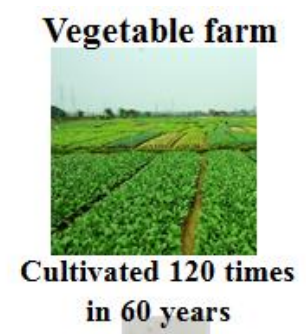

BC-H

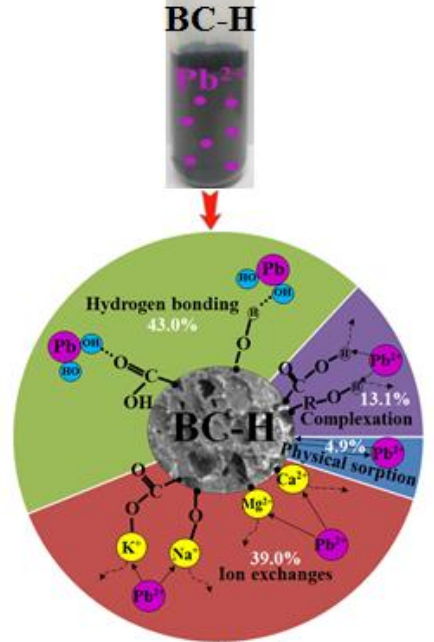

High 
The knowledge about lead $(\mathrm{Pb})$ sorption on soil-derived black carbons (SBCs) under different cultivation intensities of soils is limited. In this study, chemical and spectroscopic methods were applied to investigate the $\mathrm{Pb}$ sorption mechanisms on SBCs in soils from a forest land, a rubber plantation area, and a vegetable farm with none, less and highly intensive cultivation, respectively, that are located in the Hainan Island of China. Results showed that the specific surface area and cation exchange capacity of the SBCs from the less and highly intensive cultivation soils were 4.5- and 2.7-fold, and 1.3- and 1.8-fold higher compared to that of SBC from the no-cultivation soil, which subsequently enhanced the Pb sorption capacities of SBCs in iron exchange fraction. Ion exchange and hydrogen bonded $\mathrm{Pb}$ fractions together accounted for about $80 \%$ of total $\mathrm{Pb}$ sorbed on all SBCs at an externally added $1,000 \mathrm{mg} \mathrm{L}^{-1} \mathrm{~Pb}$ solution concentration. The $\mathrm{O}=\mathrm{C}-\mathrm{O}$ groups also played key roles in $\mathrm{Pb}$ sorption by forming complexes of $\mathrm{O}=\mathrm{C}-\mathrm{O}-\mathrm{Pb}-\mathrm{O}$ and/or $\mathrm{O}=\mathrm{C}-\mathrm{O}-\mathrm{Pb}$. Overall, $\mathrm{SBC}$ in soils under all studied cultivation intensities showed high potential to sorb $\mathrm{Pb}$ (with the maximum absorbed $\mathrm{Pb}$ amount of 46.0 to $91.3 \mathrm{mg} \mathrm{g}^{-1}$ ), and increased Pb sorption capacities of the studied soils by $18.7-21.1 \mathrm{mg} \mathrm{kg}^{-1}$ in the stable fraction (complexation). Therefore, $\mathrm{SBC}$ might be a potential environment-friendly material to enhance the $\mathrm{Pb}$ immobilization capacity of soil.

Keywords: Aging of organic carbon; biochar; sequential desorption; TG/DTG; XPS.

Abbreviations: SBC: soil-derived black carbon; BC: black carbon; SOC: soil organic carbon; SSA: specific surface area; CEC: cation exchange capacity; ICP-MS: inductively coupled plasma mass spectrometer; PTEs: potentially toxic elements; TG/DTG: thermogravimetric and differential thermogravimetric; XPS: X-ray photoelectron spectroscopy. 
Sorption of potentially toxic elements (PTEs) on solid matrices such as soils and sediments is one of the key components which determine the fate and behavior of PTEs in the environment (Chiou, 2002; Shaheen et al., 2013). It has been recognized that various forms of soil organic matter (SOM) could serve as dominant environmental "compartments" for the sorption and accumulation of PTEs (Zhou et al., 2018). Black carbon (BC) serves as a chemically and biologically stable form of SOM which exists in the soil over a long period (Liang et al., 2008; Qi et al., 2017). As one form of BCs, biochar has been found to be an excellent material for adsorption of organic pollutants (Qin et al., 2018; Zhang et al., 2019; Chen et al., 2020a) and PTEs (Ali et al., 2020; Imran et al., 2020; Yin et al., 2020). The BC may significantly affect the sorption and immobilization of PTEs in soils in a wide range of biogeochemical processes (Liang et al., 2006; Qi et al., 2017), and could be regarded as an eco-friendly and potential material to immobilize PTEs in soil (Nie et al., 2018; Bandara et al., 2020; Wei et al., 2020). Therefore, the sorption capacity and the specific mechanisms of BC for metal ion retention are of great importance in remediation of contaminated soils.

Biomass-derived $\mathrm{BC}$ exists ubiquitously in soils to varying extents as a result of deliberate vegetation burning, wildfires or emissions from energy production units (Schmidt and Noack, 2000). For example, the 2019-20 fire season in eastern Australia is attracting considerable international attention where millions of ha of temperate forest areas have been burnt during the fire (Nolan et al., 2020). It has caused serious ecological damage, along with that a large amount of charcoal, the product of the incomplete combustion of vegetation (Pereira et al., 2014), was produced. Aging of charcoals (a fraction of BCs) in the soil results in the formation of persistent soil organic carbon (SOC) (Bennett et al., 2020), including soil-derived black carbon (SBC). The SBCs from natural formation or artificial amendments, however, have high specific surface area (SSA), high cation exchange capacity (CEC), and various organic functional groups. These characteristics might increase the 
sorption capacity of PTEs on SBC during the PTE remediation processes (Qi et al., 2017). In recent years, carbon (Jaffé et al., 2013). Previous studies reported that aging of biochar following soil application changes its physiochemical properties while forming a range of biochar-derived organic materials (Mia et al., 2017). Moreover, crop cultivation practices can increase the association of charcoal with soil minerals, e.g., silicates, phosphates, aluminum oxides, and iron oxides in soils, thereby changing the elemental characteristics of charcoal (Hardy et al., 2017). The above changes in elemental compositions cause a modification of the physiochemical properties of charcoals and BC affecting their capacity to immobilize PTEs (Bandara et al., 2020). Few studies also claim that intensive cultivation of soils can change the PTE retention efficiency of SBC (Zahedifar, 2017).

It is difficult for agricultural and forestry soils to avoid PTE pollution in the process of land development and utilization due to a rapid development of social economy, industry and urbanization. Unraveling the sorption characteristics and mechanisms of PTEs on SBC from agricultural and forestry soils can help exploring the potential of $\mathrm{BC}$ or biochar in influencing the immobilization of PTEs in agricultural and forestry lands. The natural tropical rainforest in the Bawangling Forest Region $\left(108.88^{\circ}-109.33^{\circ} \mathrm{E}, 18.86^{\circ}-19.20^{\circ} \mathrm{N}\right)$ of Hainan island in China (Lu et al., 2018) was rarely disturbed for replacing its plantations, and has therefore existed for several thousand years without any cultivation (Zhang et al., 2010; Wang et al., 2017a), except a serious damage caused by people for creating more farmland or for obtaining more forest resources about 600 years ago in the 
102

103

104

about 60 years (Lu et al., 2018). Rubber trees near the Bawangling Forest Region was adopted as the secondary plantation under less intensive cultivation (cultivated about 20 years ago) system, while vegetables were grown twice a year in some lands under highly intensive cultivation system. It could be hypothesized that the physicochemical properties (e.g., CEC, elemental composition and organic functional groups) of SBCs under the less intensive cultivation system would be significantly different from those of the highly intensive cultivation system and no cultivation system, which would further affect the sorption capacities and mechanisms of $\mathrm{Pb}$ (a representative PTE) by SBCs from these systems.

The sorption mechanisms of PTEs on artificial BC (e.g., biochar) in aqueous solutions have been reported extensively (Li et al., 2019b; Yang et al., 2019; Fang et al., 2020). The major mechanisms involved in the removal of PTEs from aqueous solutions using biochars were ion-exchange, electrostatic attraction, outer-sphere and/or inner-sphere complexation, surface precipitation and/or co-precipitation (Wang et al., 2019). Several methods including potentiometric titration, sequential extraction, thermal analysis techniques such as thermogravimetric (TG) and differential thermogravimetric (DTG) analyses, and X-ray photoelectron spectroscopy (XPS) have been proven as useful methods to study the characteristics of organic functional groups and thermal stability of organic components on BCs, and analyze the interactions between carbon-based adsorbents and PTE adsorbates (Plante et al., 2009; Li et al., 2019b; Xia et al., 2019). These methods were used to investigate $\mathrm{Pb}$ sorption characteristics and mechanisms of SBCs from different soils in the current study.

In this study, we separated three SBCs from the soils under different cultivation systems (i.e., no-cultivation, less intensive cultivation, and highly intensive cultivation) in the Hainan island of China to conduct $\mathrm{Pb}$ sorption and desorption experiments on SBCs. The specific objectives of this work are to: (1) characterize the elemental composition and physicochemical properties of the SBCs; (2) explore sorption and desorption characteristics of $\mathrm{SBCs}$ for $\mathrm{Pb}$; and (3) investigate the sorption mechanisms of $\mathrm{Pb}$ onto SBCs. 


\section{Materials and methods}

\subsection{Soil collection and separation of black carbon}

Three surface soils $(0-20 \mathrm{~cm}$ depth) were collected in triplicate from the three sampling sites (without any artificial black carbon added), including a natural tropical rainforest $\left(109.09^{\circ} \mathrm{E}, 19.13^{\circ} \mathrm{N}\right)$ in the Bawangling Forest Region (Hainan Province of China), a rubber tree plantation area $\left(109.50^{\circ} \mathrm{E}, 19.53^{\circ} \mathrm{N}\right)$, and a vegetable farm $\left(109.57^{\circ} \mathrm{E}, 19.48^{\circ} \mathrm{N}\right)$ near the Bawangling Forest Region. The three collected soil samples represented no-cultivation, less intensive cultivation and highly intensive cultivation systems, respectively, and referred to as Soil 1, Soil 2 and Soil 3. Following sample collection, soil pH was determined in a soil suspension (soil:water = 1:2.5(w/v)) according to Li et al. (2020), while soil organic carbon was determined using the $\mathrm{K}_{2} \mathrm{Cr}_{2} \mathrm{O}_{7}$ method (Bao, 2000). The pH value of Soil 1, Soil 2 and Soil 3 was 4.53, 4.98 and 4.64, while the soil organic carbon content was $31.01,12.15$ and $9.10 \mathrm{~g} \mathrm{~kg}^{-1}$, respectively. The clay, silt, and sand particles were 13,24 and $63 \%$, and 18, 37 and 45\% in Soil 1 and Soil 2, respectively. The soil particle fractions with particle size less than 10 $\mu \mathrm{m}$, between 10 and $50 \mu \mathrm{m}$, and greater than $250 \mu \mathrm{m}$ were 33.0, 23.2 and 43.8\%, 40.8, 29.4 and 29.8\%, and 13.7, 56.8 and $29.5 \%$ in Soil 1, Soil 2 and Soil 3, respectively.

The SBC particles (with diameter $>0.5 \mathrm{~mm}$ ) were selected and picked from Soil 1 (no-cultivation), Soil 2 (less intensive cultivation) and Soil 3 (highly intensive cultivation) using superfine stainless forceps according to Dong et al. (2017), and referred to as BC-N, BC-L and BC-H, respectively. The SBC particles were suspended into deionized water at a ratio of 1:10 (w/v) and shaken slightly to remove soil particles adhered to the SBC particles. The SBC particles were then washed three times with deionized water, and put in a $60{ }^{\circ} \mathrm{C}$ drying oven until the weight of the particles reached a constant value (Koide et al., 2011). All SBC particles were ground and passed through a $0.15 \mathrm{~mm}$ sieve, and stored for further use. 

$1000 \mathrm{mg} \mathrm{L}^{-1}$ of $\mathrm{Pb}$ aqueous solutions (by dissolving analytical grade $\mathrm{Pb}\left(\mathrm{NO}_{3}\right)_{2}$ ) at $\mathrm{pH} 5.0$ in Erlenmeyer flasks. selected at 5.0 since the $\mathrm{pH}$ of the studied soils ranged from 4.5 to 5.0. The flasks were capped with rubber plugs, agitated on a thermostatic reciprocating shaker at $220 \mathrm{rpm}\left(25^{\circ} \mathrm{C}\right)$ for $24 \mathrm{~h}$. Then, the aqueous solutions were filtered through a $0.45 \mu \mathrm{m}$ cellulose-acetate membrane filter paper, and the residual $\mathrm{Pb}$-loaded SBCs was washed with deionized water, and air-dried at room temperature prior to further analysis.

\subsection{Characterization of black carbon}

Total hydrogen $(\mathrm{H})$, carbon $(\mathrm{C})$, and nitrogen $(\mathrm{N})$ contents of SBCs were measured using an elemental analyzer (Vario ELIII - Elementary Company, Germany). The oxygen (O) content was calculated by the difference assuming that the SBC was composed only of H, C, N, and O (Wu et al. 2012). Ash content of the SBCs was determined by placing crucibles containing the samples in a muffle furnace at $750^{\circ} \mathrm{C}$ for $6 \mathrm{~h}$ (D1762-84, 2007). The crucibles were kept with lids in a desiccator for $1 \mathrm{~h}$ for cooling, and then weighed. Pore volume and SSA of SBCs were measured by $\mathrm{N}_{2}$ adsorption isotherms (ASAP2460, Micromeritics, USA) applying the Brunauer-Emmett-Teller (BET) equation (Brunauer et al., 1938). The contents of acidic functional groups of SBCs were determined by the Boehm titration method (Boehm, 1994). The CEC of SBCs was determined following $1 \mathrm{M}$ ammonium acetate ( $\mathrm{pH}$ 7) extraction method (Wu et al., 2017). In order to measure total carbon content of SBCs in soils, soil samples were digested using peroxide to remove non-BC. Twenty 
of 30-50 mL until no further bubbles appeared), and heated on a hot plate at $90{ }^{\circ} \mathrm{C}$ to ensure maximum non-BC removal (Liang et al., 2006). Total carbon content of SBCs in soils was then measured using the $\mathrm{K}_{2} \mathrm{Cr}_{2} \mathrm{O}_{7}$-heating method (Bao, 2000). The total carbon content of BC-N, BC-L and BC-H in Soil 1, Soil 2 and Soil 3 was $0.81,1.58$ and $1.08 \mathrm{~g} \mathrm{~kg}^{-1}$, therefore, the weight content of BC-N, BC-L and BC-H in the soils was $1.65,3.30$ and $2.36 \mathrm{~g} \mathrm{~kg}^{-1}$, respectively $\left(\mathrm{W}_{\mathrm{BC}}=\mathrm{T}_{\mathrm{BC}} \times \mathrm{E}_{\mathrm{C} \%}\right.$, while $\mathrm{W}_{\mathrm{BC}}, \mathrm{T}_{\mathrm{BC}}$ and $\mathrm{E}_{\mathrm{C} \%}$ refer to weight content of SBCs in soils, total carbon content of SBCs in soils, and carbon percentage of SBCs, respectively).

Thermogravimetric (TG) and differential thermogravimetric (DTG) analyses curves were obtained using a thermogravimetric analyzer (SDT Q600, TA Instruments, USA) at a heating rate of $10{ }^{\circ} \mathrm{C} \min ^{-1}$ from $30{ }^{\circ} \mathrm{C}$ to $1000{ }^{\circ} \mathrm{C}$ under a controlled atmosphere of $\mathrm{N}_{2}\left(50 \mathrm{~mL} \mathrm{~min}^{-1}\right)$ with an initial material mass of $30 \mathrm{mg}$. Fourier transform infrared (FTIR) analysis of SBCs before Pb sorption was conducted according to Wu et al. (2016). Spectra were collected using a TENSOR 27 FTIR spectrophotometer (Bruker Company, Germany) scanning from 4000 to $400 \mathrm{~cm}^{-1}$ (wavenumber) at a resolution of $2 \mathrm{~cm}^{-1}$. The X-ray photoelectron spectroscopy (XPS, AXIS SUPRA, Japan) was used to measure the bonding energies of $\mathrm{C}, \mathrm{O}$, and $\mathrm{Pb}$ on the $\mathrm{SBCs}$ and $\mathrm{Pb}$-loaded SBCs prepared at $1000 \mathrm{mg} \mathrm{L}^{-1} \mathrm{~Pb}$ aqueous solution (scans for C 1s, O 1s and $\mathrm{Pb} 4 \mathrm{f}$ ). Samples were freeze-dried, ground to powder in the anaerobic chamber, and pressed into pellets. The energy range was $0-1000 \mathrm{eV}$ for wide-scan spectra (Li et al., 2020).

\subsection{Sorption experiments}

A stock solution of $1000 \mathrm{mg} \mathrm{L^{-1 }} \mathrm{Pb}$ was prepared by dissolving $\mathrm{Pb}\left(\mathrm{NO}_{3}\right)_{2}$ in $0.01 \mathrm{M} \mathrm{NaNO}_{3}$ solution. Sorption kinetics was determined by determining sorption amounts at various time intervals $(5,10,15,20,30$, $40,60,120,240,480,960$ and $1440 \mathrm{~min})$ at $\mathrm{pH}$ 5.0. The $\mathrm{pH}$ value of suspension was adjusted with $0.1 \mathrm{M} \mathrm{NaOH}$ or $0.1 \mathrm{M} \mathrm{HNO}_{3}$ solution to simulate a typical soil water situation (Li et al., 2019b). Sorption isotherm 

$\mathrm{K}^{+}, \mathrm{Mg}^{2+}$ and $\mathrm{Ca}^{2+}$ ) from the original SBCs in the supernatant (under $\mathrm{Pb}$ concentration of $1000 \mathrm{mg} \mathrm{L}^{-1}$ ) were also analyzed by ICP-MS. The corresponding release of $\mathrm{Na}^{+}, \mathrm{K}^{+}, \mathrm{Mg}^{2+}$ and $\mathrm{Ca}^{2+}$ from the $\mathrm{SBCs}$ with deionized water (at the same $\mathrm{pH}$ ) served as the control. All treatments in the sorption experiments were conducted in triplicate.

\subsection{Desorption experiments}

Lead fractionation in Pb-loaded SBCs (prepared in section 2.2 of this study) during desorption experiments was conducted using the method modified from Andreas and Zhang (2014). The sorbed $\mathrm{Pb}$ was fractionated into sorption fraction is affected by van der Waals force between $\mathrm{Pb}$ and $\mathrm{SBC}$ surface, ion exchange fraction is attributed to the cation exchange between $\mathrm{Pb}$ and other cations on $\mathrm{SBC}$ surface, hydrogen bonding fraction is formed by hydrogen bonds between $\mathrm{Pb}$ forming hydrates $\left[\mathrm{Pb}\left(\mathrm{H}_{2} \mathrm{O}\right)_{6}^{2+}\right]$ and oxygen-containing functional groups on SBC surface, and complexation fraction is influenced by coordination reaction of $\mathrm{Pb}$ on $\mathrm{SBCs}$ surface 

using ICP-MS.

The sorption kinetics of $\mathrm{Pb}$ onto SBC was analyzed by the pseudo-first-order and pseudo-second-order models, the sorption isotherms of Pb onto SBCs were analyzed by the Langmuir and Freundlich models (Text S1 of the Supporting Information). hydrogen bonding fraction (bond with oxygen-containing function groups, $\left.\mathrm{Q}_{\text {hyd }}\right)$, complexation fraction $\left(\mathrm{Q}_{\mathrm{com}}\right)$ and total sorption fraction $\left(\mathrm{Q}_{\mathrm{tot}}\right)$ were calculated by the Langmuir model fitting.

\subsection{Statistical analysis} spectra were done using the software Origin 9.0 (Origin Lab, USA).

Results were expressed on a dry mass basis, and shown as mean \pm standard deviation (SD) of three replicates per treatment. The standard deviation bars of results were added in specific figures. The fitting of the Langmuir and Freundlich models, pseudo-first-order and pseudo-second-order models, and the graphing of XPS

\section{Results and discussion}

\subsection{Properties of soil-derived black carbons}


Soil 1 (BC-N) under no cultivation (the control). Values were presented by 1.64 and $2.36 \% \mathrm{~N}$ contents of BC-L

235

and $\mathrm{BC}-\mathrm{H}$, respectively, while $0.73 \%$ for $\mathrm{BC}-\mathrm{N}$ (the control). The $\mathrm{H}$ and $\mathrm{O}$ contents of SBCs were slightly increased with the increasing cultivation intensity from the control (3.61 and 46.5\%) to low (3.87 and $46.6 \%)$ and high (3.90 and 47.8\%) (Table 1). However, the C content slightly decreased (49.1, 47.9 and $45.9 \% \mathrm{C}$ contents of BC-N, BC-L and BC-H, respectively) under the elevated cultivation intensity (Table 1). This might be attributed to the enhanced disturbances of soils and weathering of SBCs by various cultivation practices, e.g., ploughing, wetting and drying, and water and fertilizer management (Hardy et al., 2017). During farming of the land, the above practices inputted more $\mathrm{N}$ into the soil than the no-cultivation system, and accelerated the decomposition of $\mathrm{BCs}$ in the soil by bringing down the $\mathrm{C}: \mathrm{N}$ ratio (Hardy et al., 2017). As a result, labile C-containing groups such as aromatic and aliphatic groups of SBCs were decomposed by microorganisms (Kuzyakov et al., 2009). Meanwhile, an increasing proportion of $\mathrm{H}$ and O-rich functional groups such as carboxyl, carbonyl and O-alkyl were formed on SBCs during the BC mineralization (Kuzyakov et al., 2009; Mia et al., 2017). Additionally, a high proportion of $\mathrm{N}$-containing groups could increase the reaction ratio of positively charged $\mathrm{N}$-containing functional groups in soil to negatively charged $\mathrm{C}$-containing functional groups on SBCs under a high cultivation intensity (Hardy et al., 2017; Mia et al., 2017; Wang et al., 2018). This might contribute to the increase in N content of SBCs with increasing soil cultivation intensity. Similarly, Hardy et al. (2017) reported that charcoal in cropland over long cultivation time had higher $\mathrm{O}$ and $\mathrm{H}$ contents and $\mathrm{N}$-alkyl groups than short cultivation duration due to enhanced weathering of various $\mathrm{C}$ substrates.

The higher the ratio of $\mathrm{H} / \mathrm{C}$ and $\mathrm{O} / \mathrm{C}$ in $\mathrm{SBC}$, the lower is the aromaticity of SBC, and the more abundant is the organic functional groups such as hydroxyl and carboxyl groups (Wu et al., 2012; Wu et al., 2016). The order of $\mathrm{H} / \mathrm{C}$ and $\mathrm{O} / \mathrm{C}$ ratios of SBCs was: $\mathrm{BC}-\mathrm{H}>\mathrm{BC}-\mathrm{L}>\mathrm{BC}-\mathrm{N}$ (Table 1). Thus, the $\mathrm{H} / \mathrm{C}$ and $\mathrm{O} / \mathrm{C}$ ratios increased under elevated weathering and cultivation disturbances of SBCs. These might be attributed to the 
increased phenol, carbonyl and carboxyl functional groups which were created by the oxidation of SBC surfaces during the aging of BCs under high cultivation intensity (Cao et al., 2019). The total content of acidic functional groups (the sum of carboxylic acid ( $\mathrm{RCOOH})$, weak acid ester (RCOR'), and phenolic hydroxyl groups (AOH)) in BC-H (1.70 mmol g $\left.{ }^{-1}\right)$ and BC-L $\left(1.71 \mathrm{mmol} \mathrm{g}^{-1}\right)$ was higher than that of BC-N (1.57 $\mathrm{mmol} \mathrm{g}^{-1}$; Table 1), which also indicated that hydroxylation and carboxylation of SBCs could be enhanced by increased cultivation intensity and aging. As reported by Mukherjee et al. (2014), the advanced oxidation of SBCs most likely created phenol, carboxyl and carbonyl functional groups at the edge of aromatic rings on the surfaces. Mia et al. (2017) found that progressive aging of biochar (artificial BC) also led to a gradual formation of surface functional groups such as phenolic, carboxyl, and carbonyl groups. The results of this study are consistent with those of previous studies, showing that aging of charcoals in soil resulted in the oxidation of their surfaces (Lehmann et al., 2005; Hardy et al., 2017). Accordingly, both $\mathrm{H} / \mathrm{C}$ and $\mathrm{O} / \mathrm{C}$ ratios of charcoal could be increased through elevated aging intensities (Cheng et al., 2008; Pereira et al., 2014).

The CEC of three SBCs ranged from $128-227 \mathrm{cmol} \mathrm{kg}^{-1}$ (Table 1) with the order of BC-H $(227.3 \mathrm{cmol}$ $\left.\mathrm{kg}^{-1}\right)>\mathrm{BC}-\mathrm{L}\left(166.4 \mathrm{cmol} \mathrm{kg}^{-1}\right)>\mathrm{BC}-\mathrm{N}\left(128 \mathrm{cmol} \mathrm{kg}^{-1}\right)$. Under the low and high cultivation intensity of the soils, a gradual aging resulted in the value of SSA of BC-L and BC-H to be 4.5- and 2.7-fold higher than that of BC-N (Table 1). Thus, more sorption sites might be presented on the surface of BC-L and BC-H than BC-N, which could increase CEC of SBCs. The higher total content of acidic functional groups of BC-L and BC-H might also be responsible for the increase in CEC compared to that of BC-N in this study. Similarly, previous studies reported that CEC of charcoal increased over increasing aging intensity (Cheng et al., 2008). The CEC, variety of active functional groups and SSA were reported to affect the sorption capacities of biochar toward PTEs, including Pb sorption and immobilization (Lu et al., 2017; Wu et al., 2017; Li et al., 2019b). 

acid, and formation of $\mathrm{C}-\mathrm{H}$ and $\mathrm{R}-\mathrm{CH}_{3}$ contained functional groups on SBCs during the increased cultivation intensity of the soils.

\subsection{Sorption and desorption of $\mathrm{Pb}$ from Pb-loaded SBCs}

The kinetics of $\mathrm{Pb}$ sorption on the three SBCs at $\mathrm{pH}$ of 5.0 are presented in Fig. S1 (Supporting Information).

The sorption kinetics of $\mathrm{Pb}$ on the three SBCs were expressed well by the pseudo-second-order model, rather chemisorption processes (Lu et al., 2012; Bandara et al., 2020). process (Xia et al., 2019). 
sorption of $\mathrm{Pb}$ on SBC. Wang et al. (2011) showed that the wheat-residue derived $\mathrm{BC}$ could sorb $\mathrm{Pb}$ up to 0.65 mmol g $\mathrm{g}^{-1}$ (equal to $134 \mathrm{mg} \mathrm{g}^{-1}$ ) at $\mathrm{Pb}$ concentration of $20 \mathrm{mmol} \mathrm{L}^{-1}$. The sorption capacity of wheat-residue derived $\mathrm{BC}$ was higher than that of the three SBCs in this study. However, the maximum amount of $\mathrm{Pb}$ sorption to biochar (artificial BC) produced from different agricultural biomass might range from 13.1 to $88.7 \mathrm{mg} \mathrm{g}^{-1}$ (Table S3). Unraveling the sorption mechanisms of $\mathrm{Pb}$ to different SBCs can help to understand the difference in the sorption capacities of SBCs for $\mathrm{Pb}$. The exact $\mathrm{Pb}$ fractions on Pb-loaded SBCs would be able to reveal the related sorption mechanisms of $\mathrm{Pb}$ to SBCs.

In the desorption experiments, the total $\mathrm{Pb}$ amount $\left(\mathrm{Q}_{\mathrm{tot}}\right)$ and $\mathrm{Pb}$ amount of four sorbed fractions, e.g., physical sorption $\left(\mathrm{Q}_{\text {phy }}\right)$, ion exchange $\left(\mathrm{Q}_{\mathrm{exc}}\right)$, hydrogen bonding $\left(\mathrm{Q}_{\text {hyd }}\right)$ and complexation $\left(\mathrm{Q}_{\text {com }}\right)$ fractions are shown in Fig. 3. With the increase of initial concentration of $\mathrm{Pb}$, the amount of $\mathrm{Pb}$ in $\mathrm{Q}_{\text {phy }}, \mathrm{Q}_{\text {com }}, \mathrm{Q}_{\text {hyd }}$, and $\mathrm{Q}_{\mathrm{exc}}$ fractions reached the sorption equilibrium successively, indicating that the exact saturation order of the four $\mathrm{Pb}$ fractions was $\mathrm{Q}_{\text {phy }}, \mathrm{Q}_{\text {com }}, \mathrm{Q}_{\text {hyd }}$, and $\mathrm{Q}_{\text {exc }}$. The $\mathrm{Q}_{\mathrm{exc}}, \mathrm{Q}_{\text {hyd }}, \mathrm{Q}_{\text {com }}$ and $\mathrm{Q}_{\text {tot }}$ on the three types of Pb-loaded SBCs were all found to be well fitted to the Langmuir model (Table S4) with high $\mathrm{r}^{2}$ values ranging from 0.971 to 0.987 , which was attributed to the fact that $\mathrm{Pb}$ desorption from $\mathrm{Pb}$-loaded $\mathrm{SBCs}$ was a reverse process on $\mathrm{Pb}$ sorption to SBCs (Andreas and Zhang, 2014).

The percentage of sorbed $\mathrm{Pb}$ in $\mathrm{Q}_{\mathrm{hyd}}$ and $\mathrm{Q}_{\mathrm{com}}$ fractions of $\mathrm{Pb}$-loaded SBCs (at $\mathrm{Pb}$ concentration of $1000 \mathrm{mg}$ $\mathrm{L}^{-1}$ ) significantly decreased from 48.9 and $20.1 \%$ to 43.4 and $12.7 \%$ under no-cultivation in comparison to the low cultivation intensity, while decreased to 43.0 and $13.1 \%$ under high cultivation intensity (Fig. 4). The percentage of $\mathrm{Pb}$ in the $\mathrm{Q}_{\mathrm{exc}}$ fraction on SBCs however increased from $26.8 \%$ to 35.1 and $39.0 \%$, respectively, from no-cultivation to low and high cultivation intensities. Results showed that $\mathrm{Q}_{\mathrm{exc}}$ and $\mathrm{Q}_{\mathrm{hyd}}$ were the two most important $\mathrm{Pb}$ fractions on the three $\mathrm{Pb}$-loaded SBCs. The sum of $\mathrm{Pb}$ amounts in $\mathrm{Q}_{\mathrm{exc}}$ and $\mathrm{Q}_{\text {hyd }}$ of the three $\mathrm{Pb}$-loaded SBCs was ranging from 35.2 to $56.1 \mathrm{mg} \mathrm{g}^{-1}$, and accounting for 75.7 to $82.0 \%$ of total sorbed $\mathrm{Pb}$ 
322

323

(Table S5 and Fig. 4). Previous research also reported that biochar could remove metal ions from aqueous solutions by various mechanisms including electrostatic attraction, complex formation, reduction and precipitation (Lu et al., 2012; Li et al., 2019b). Similarly, Andreas and Zhang (2014) reported that metal sorption onto soil-derived humin (a specific organic matter) in freshwater media was dominated by hydrogen bonding and ion exchange fractions.

The content of BC-N, BC-L and BC-H in the soils was 2.85, 5.69 and $4.07 \mathrm{~g} \mathrm{~kg}^{-1}$, while $\mathrm{Pb}$ amount in the $\mathrm{Q}_{\mathrm{com}}$ fraction of these Pb-loaded SBCs was $11.52,5.68$ and $8.95 \mathrm{mg} \mathrm{g}^{-1}$, respectively (Table S5 and Fig. 4). The complexation $\left(\mathrm{Q}_{\mathrm{com}}\right)$ fraction of $\mathrm{Pb}$ was presented to be stable since the extracting agents such as ultrapure water, $\mathrm{CH}_{3} \mathrm{COONH}_{4}(1 \mathrm{M}, \mathrm{pH}=7), \mathrm{CH}_{3} \mathrm{COOH}(4.37 \mathrm{M})$ and $\mathrm{NH}_{2} \mathrm{OH} \cdot \mathrm{HCl}(0.04 \mathrm{M})$ could not extract this $\mathrm{Pb}$ fraction (Andreas and Zhang, 2014) from the Pb-loaded SBCs. Therefore, we inferred that the BC-N, BC-L and BC-H might increase the capacity of Soil 1, Soil 2 and Soil 3 to adsorb Pb as a stable (complexation) fraction by 19.0, 18.7 and $21.1 \mathrm{mg} \mathrm{kg}^{-1}$ (Table S5), respectively.

\subsection{Sorption mechanisms of $\mathrm{Pb}$ to SBCs}

It was reported that the efficacy of various biochars derived from different biomass materials to adsorb PTE contaminants depends on its properties, e.g., surface area, pore size distribution, ion-exchange capacity (Bandara et al., 2020) and surface oxygen-containing functional groups (Xia et al., 2019) representing different sorption mechanisms. Accordingly, the sorption mechanisms of $\mathrm{Pb}$ onto SBCs were divided into the following four parts.

(1) Physical sorption: The orders of $\mathrm{Q}_{\text {phy }}$ on Pb-loaded SBCs and SSA of SBCs were both in the order: BC-L > BC-H > BC-N (Table S5 and Table 1), while the SSA values of SBCs was highly correlated to $\mathrm{Q}_{\text {phy }}$ fractions on Pb-loaded SBCs with a correlation coefficient $\left(\mathrm{R}^{2}\right)$ value of 0.94 (Fig. S2a). Similar results were reported by Zhang et al. (2019) who realized that the surface area of a sludge-based biochar was improved after 
activation by different activators, thus improving its physical $\mathrm{Pb}$ sorption capacity. Moreover, Ngambia et al. (2019) found that tunnels on the rods of sludge derived carbon provided a high surface area, extra sorption sites and interspace for easy contamination diffusion contributing to surface physical adsorption.

(2) Ion exchange: The CEC values of SBCs were highly correlated to the $\mathrm{Q}_{\text {exe }}$ fractions of Pb-loaded SBCs with a correlation coefficient $\left(\mathrm{R}^{2}\right)$ of 0.833 (Fig. S2b). Moreover, the CEC values of SBCs and $\mathrm{Q}_{\text {exe }}$ fractions of $\mathrm{Pb}$ on Pb-loaded SBCs all followed the order: BC-H > BC-L > BC-N (Table S5 and Table 1). Therefore, the Qexe fraction of $\mathrm{Pb}$-loaded $\mathrm{SBCs}$ might be mainly attributed to the cation exchange mechanism of $\mathrm{Pb}$ sorption on SBCs.

The sum amounts of $\mathrm{Na}^{+}, \mathrm{K}^{+}, \mathrm{Mg}^{2+}$ and $\mathrm{Ca}^{2+}$ released in the supernatants after $\mathrm{Pb}$ sorption onto $\mathrm{BC}-\mathrm{N}, \mathrm{BC}-\mathrm{L}$ and $\mathrm{BC}-\mathrm{H}$ were equivalent to $13.3,15.6$ and $18.6 \mathrm{mg} \mathrm{Pb} \mathrm{g}^{-1}$, accounting for $23.1,34.9$ and $27.2 \%$ of the total $\mathrm{Pb}$ sorbed by BC-N, BC-L and BC-H (prepared under $\mathrm{Pb}$ concentration of $1000 \mathrm{mg} \mathrm{L}^{-1}$ ), respectively (Table S6). The sum amounts of $\mathrm{Na}^{+}$and $\mathrm{K}^{+}$(mono-valent cations), which could be related to the electrostatic ion exchange with $\mathrm{Pb}$ (Lu et al., 2012) since they cannot form precipitates or be coordinated with surface functional groups of BCs, were equivalent to 5.32, 3.0 and $3.67 \mathrm{mg} \mathrm{Pb} \mathrm{g}^{-1}$ accounting for $34.5,19.1$ and $13.8 \%$ of the Qexc values on Pb-loaded BC-N, BC-L and BC-H, respectively (Table S6). Meanwhile, the sum amounts of $\mathrm{Mg}^{2+}$ and $\mathrm{Ca}^{2+}$ (divalent alkaline earth cations), which could originate from the exchange sites of inorganic minerals and the chelated surface functional groups such as $\mathrm{R}-\mathrm{COO}-\mathrm{Me}$ or $\mathrm{R}-\mathrm{O}-\mathrm{Me}$ on $\mathrm{SBCs}$, were equivalent to 7.95, 12.6 and $15.0 \mathrm{mg} \mathrm{Pb} \mathrm{g}^{-1}$ accounting for 51.6, 80.2 and $56.1 \%$ of the $\mathrm{Q}_{\mathrm{exc}}$, respectively (Table S6). Our results showed that the exchange sites adsorbed or chelated $\mathrm{Pb}$ fractions in $\mathrm{Q}_{\mathrm{exc}}$ of $\mathrm{Pb}$-loaded $\mathrm{SBCs}$ were far more than that of the electrostatically ion exchanged $\mathrm{Pb}$ fraction, indicating that chelation might have played a more important role during the sorption process (Lu et al., 2012). Similar result was reported by Li et al. (2019b) that ion exchange was the main mechanism for $\mathrm{Pb}$ sorption by coconut-fiber biochar with electrostatic ion exchange and chelation 
processes.

(3) Hydrogen bonding: The results of TG and DTG thermograms of the three SBCs are shown in Fig. S3. The TG and DTG analyses detected three endothermic peaks between 30 and $180{ }^{\circ} \mathrm{C}, 300$ and $350{ }^{\circ} \mathrm{C}$, and 380 and $560{ }^{\circ} \mathrm{C}$ for all samples (Fig. S3). Previous studies ascribed the endothermic peak at temperatures below $200{ }^{\circ} \mathrm{C}$ to the loss of adsorbed water, while that near $325^{\circ} \mathrm{C}$ to decarboxylation (volatilization of $-\mathrm{COOH}$ ) and further dehydroxylation (volatilization of $-\mathrm{OH}$ ) of surface organic functional groups, and that around $475{ }^{\circ} \mathrm{C}$ to the thermal reaction of the aromatic nuclei of organic matter (Plante et al., 2009). Carbohydrates and other aliphatic compounds would be pyrolyzed at 300 to $350{ }^{\circ} \mathrm{C}$ in the $\mathrm{TG}$ analysis (Plante et al., 2009), the weight loss of SBCs (Fig. S3; attributed to volatilization of $-\mathrm{COOH}$ and $-\mathrm{OH}$ ), however, were highly correlated to the sum content of $\mathrm{AOH}$ and $\mathrm{RCOOH}$ groups (Table 1) with a $\mathrm{R}^{2}$ value of 0.966 (Fig. S2c).

Moreover, the sum contents of $\mathrm{AOH}$ and $\mathrm{RCOOH}$ of SBCs were significantly correlated with $\mathrm{Pb}$ amount in the $\mathrm{Q}_{\text {hyd }}$ fraction (with a $\mathrm{R}^{2}$ value of 0.833 ; Fig. S2d). This might be attributed to the activities of $-\mathrm{COOH}$ and $-\mathrm{OH}$ groups to adsorb $\mathrm{Pb}$ in aqueous solution through hydrogen bonding. It was reported that $\mathrm{Pb}$ would be present mainly as the species of $\mathrm{Pb}^{2+}$ at $\mathrm{pH} 4$ in aqueous solution, then the amount of $\mathrm{Pb}^{2+}$ would decrease with an increase of $\mathrm{pH}$ to 5.5 due to $\mathrm{Pb}(\mathrm{OH})^{+}$formation (Ucun et al., 2003). Ucun et al. (2003) observed $\mathrm{Pb}$ precipitation $\left(\mathrm{Pb}(\mathrm{OH})_{2}\right)$ when the initial $\mathrm{pH}$ of a biosorption medium was adjusted to $\mathrm{pH} 5.5$. Thus, $\mathrm{Pb}^{2+}$ and $\mathrm{Pb}(\mathrm{OH})^{+}$were likely to be adsorbed onto SBCs through hydrogen bonding at $\mathrm{pH} 5.0$ as the Qhyd fraction in this study.

(4) Complexation: In order to elucidate the complexation mechanism, the XPS spectra of C and O groups on the surface of SBCs with and without $\mathrm{Pb}$ loading were obtained for $\mathrm{C} 1 \mathrm{~s}, \mathrm{O} 1 \mathrm{~s}$ and $\mathrm{Pb} 4 \mathrm{f}$ regions, and the corresponding changes in the functional groups were determined (Fig. 5 and Table 2). The peak at the binding energy of $\mathrm{Pb} 4 \mathrm{f}$ between 138 and $143 \mathrm{eV}$ was found in all Pb-loaded SBC samples (Fig. 5b), which confirmed 
that $\mathrm{Pb}$ was successfully complexed by the functional groups on SBCs. The binding energy of $\mathrm{Pb} 4 \mathrm{f} 5 / 2$ and 4f7/2 on Pb-loaded SBCs decreased to $143.79 \mathrm{eV}$ and $138.89 \mathrm{eV}$ in comparison with $\mathrm{Pb}\left(\mathrm{NO}_{3}\right)_{2}$ that centered at $145.0 \mathrm{eV}$ and $139.9 \mathrm{eV}$ (Batrusaitis et al., 2012; Xin et al., 2012), respectively, indicating the presence of strong affinity between $\mathrm{SBC}$ and $\mathrm{Pb}$ ions by newly formed $\mathrm{Pb}-\mathrm{O}$ groups (Zhang et al., 2017).

As shown in Fig. $5 \mathrm{c}-\mathrm{h}$, three principal $\mathrm{C}$ species, i.e., $\mathrm{C}-\mathrm{C} / \mathrm{C}=\mathrm{C} / \mathrm{C}-\mathrm{H}$ (hydrocarbon) at $284.7 \mathrm{eV}, \mathrm{C}-\mathrm{O}$ (aromatic) at $286.4 \mathrm{eV}$ and $\mathrm{C}=\mathrm{O} / \mathrm{O}-\mathrm{C}=\mathrm{O}$ (carboxylic carbon) at $288.4 \mathrm{eV}$, and two $\mathrm{O}$ species such as $\mathrm{C}-\mathrm{O}$ at $531.9 \mathrm{eV}$ and $\mathrm{C}=\mathrm{O}$ at $532.8 \mathrm{eV}$ were identified in the three SBC samples (Deng et al. 2017; Xia et al., 2019). After $\mathrm{Pb}$ sorption, the peak intensities of $\mathrm{C}-\mathrm{O}$ (aromatic) significantly decreased, while that of $\mathrm{O}=\mathrm{C}-\mathrm{O}$ (carboxylic carbon) and $\mathrm{C}=\mathrm{O}$ significantly increased (Table 2). These results indicated that $\mathrm{O}=\mathrm{C}-\mathrm{O}$ groups played key roles in $\mathrm{Pb}$ sorption by forming complexes of $\mathrm{O}=\mathrm{C}-\mathrm{O}-\mathrm{Pb}$ and/or $\mathrm{O}=\mathrm{C}-\mathrm{O}-\mathrm{Pb}-\mathrm{O}$ (Yamada et al., 2014; Wang et al., 2015).

Overall, the above four mechanisms all likely attributed to Pb sorption onto SBCs, while they had various degrees of contributions. However, the amount of $\mathrm{Pb}$ adsorbed onto SBCs was dominated by the ion exchange, hydrogen bonding and complexation fractions. The amount of $\mathrm{Pb}$ in the physical sorption, ion exchange and hydrogen bonding fractions on Pb-loaded SBCs were highly correlated with SSA, CEC and the sum contents of hydroxyl and carboxyl functional groups on SBCs, respectively.

\section{Conclusions}

The amount of $\mathrm{Pb}$ adsorbed onto different SBCs was dominated by the ion exchange and hydrogen bonded fractions, which together accounted for about $80 \%$ of the total sorbed $\mathrm{Pb}$, and was mainly attributed to CEC and hydrogen bonding capacities of free carboxyl and hydroxyl groups of SBCs. The increased cultivation intensity and aging of SBCs increased the $\mathrm{H} / \mathrm{C}, \mathrm{O} / \mathrm{C}$ ratios and $\mathrm{CEC}$ of the SBCs compared to that with no cultivation. 

cultivation intensity of soils. The maximum $\mathrm{Pb}$ sorption capacities of SBCs in this study were as high as that of

412 biochars produced from various agricultural biomasses. Moreover, the SBCs might increase the Pb sorption capacities of the studied soils by $18.7-21.1 \mathrm{mg} \mathrm{kg}^{-1}$ in stable fractions, which might not be released readily. stable form. Increasing SBC content in soil during land management and utilization could befittingly be an environment-friendly method to enhance the potential $\mathrm{Pb}$ immobilization capacity of soils. Further research should be carried out to determine the PTE sorption capacity of SBCs in ecologically and climatically different soils, so as to establish a database of PTE immobilization capacity of SBCs in soils.

\section{Acknowledgements}

This work was financially supported by the National Key Research and Development Program of China

\section{References}

Ali, S., Rizwan, M., Shakoor, M.B., Jilani, A., Anjum, R., 2020. High sorption efficiency for As(III) and As(V) from aqueous

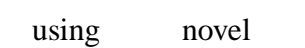

almond biochar,
243

125330. 
Andreas, R., Zhang, J., 2014. Characteristics of adsorption interactions of cadmium(II) onto humin from peat soil in freshwater and seawater media. B. Environ. Contam. Tox. 92, 352-357. https://doi.org/10.1007/s00128-014-1205-x

Bandara, T., Franks, A., Xu, J., Bolan, N., Wang, H., Tang, C., 2020. Chemical and biological immobilization mechanisms of potentially toxic elements in biochar-amended soils. Crit. Rev. Environ. Sci. Technol. 50, 903-978. doi:10.1080/10643389.2019.1642832

Bao, S., 2000. Chemical Analysis for Agricultural Soil. China Agriculture Press, Beijing.

Batrusaitis, J., Chen, H.H., Rubasinghege, G., Grassian, V.H., 2012. Heterogeneous atmospheric chemistry of lead oxide particles with nitrogen dioxide increases lead solubility: environmental and health implications. Environ. Sci. Technol. 46 (23), 12806-12813. https://doi.org/10.1021/es3019572

Bennett, L.T., Hinko-Najera, N., Aponte, C., Nitschke, C.R., Fairman, T.A., Fedrigo, M., Kasel, S., 2020. Refining benchmarks for soil organic carbon in Australia's temperate forests. Geoderma 368, 11424. https://doi.org/10.1016/j.geoderma.2020.114246

Boehm, H.P., 1994. Some aspects of the surface chemistry of carbon blacks and other carbons. Carbon 32 (5), 759-769. https://doi.org/10.1016/0008-6223(94)90031-0

Brunauer, S., Emmett, P.H., Teller, E., 1938. Adsorption of gases in multimolecular layers. J. Am. Chem. Soc. 60 (2), 309-319. https://doi.org/10.1021/ja01269a023

Cao, Y., Jing, Y., Hao, H., Wang, X., 2019. Changes in the physicochemical characteristics of peanut straw biochar after freeze-thaw and dry-wet aging treatments of the biomass. BioResources 14(2), 4329-4343. https://doi.org/10.15376/biores.14.2.4329-4343

Chen, H., Yang, X., Wang, H., Sarkar, B., Shaheen, S.M., Gielen, G., Bolan, N., Guo, J., Che, L., Sun, H., Rinklebe, J., 2020 a. Animal carcass- and wood-derived biochars improved nutrient bioavailability, enzyme activity, and plant growth in metal-phthalic acid ester co-contaminated soils: A trial for reclamation and improvement of degraded soils. Journal of 
Chen, Y., Lee, S., Tahmasebi, A., Bai, J., Vongsvivut, J., Yu, J., 2020b. Chemical structure transformation during the later stage of plastic layers during coking using Synchrotron infrared microspectroscopy technique. Fuel. 273, 117764. https://doi.org/10.1016/j.fuel.2020.117764

Cheng, C.-H., Lehmann, J., Engelhard, M.H., 2008. Natural oxidation of black carbon in soils: Changes in molecular form and surface charge along a climosequence. Geochim. Cosmochim. Ac. 72, 1598-1610. https://doi.org/10.1016/j.gca.2008.01.010

Chiou, C.T., 2002. Partition and Adsorption of Organic Contaminants in Environmental Systems. Wiley-Interscience. https://doi.org/10.1016/S0304-3894(02)00361-8

D1762-84, 2007. Standard Test Method for Chemical Analysis of Wood Charcoal. American Society for Testing and Materials, Conshohocken, PA.

Deng, J., Liu, Y., Liu, S., Zeng, G., Tan, X., Huang, B., Tang, X., Wang, S., Hua, Q., Yan, Z., 2017. Competitive adsorption of $\mathrm{Pb}(\mathrm{II}), \mathrm{Cd}(\mathrm{II})$ and $\mathrm{Cu}$ (II) onto chitosan-pyromellitic dianhydride modified biochar. J. Colloid. Interface. Sci. 506, 355-364. https://doi.org/10.1016/j.jcis.2017.07.069

Dodson, J., Li, J., Lu, F., Zhang, W., Yan, H., Cao, S., 2019. A late pleistocene and holocene vegetation and environmental record from shuangchi maar, hainan province, South China. Palaeogeogr. Palaeocl. 523, 89-96. https://doi.org/10.1016/j.palaeo.2019.03.026

Dong, X., Li, G., Lin, Q., Zhao, X., 2017. Quantity and quality changes of biochar aged for 5 years in soil under field conditions. Catena 159, 136-143. https://doi.org/10.1016/j.catena.2017.08.008

Fang, Z., Gao, Y., Bolan, N., Shaheen, S.M., Xu, S., Wu, X., Xu, X., Hu, H., Lin, J., Zhang, F., Li, J., Rinklebe, J., Wang, H., 2020. Conversion of biological solid waste to graphene-containing biochar for water remediation: A critical review. Chem. Eng. J. 390, 124611. https://doi.org/10.1016/j.cej.2020.124611 
Hardy, B., Leifeld, J., Knicker, H., Dufey, J.E., Deforce, K., Cornélis, J.T., 2017. Long term change in chemical properties of preindustrial charcoal particles aged in forest and agricultural temperate soil. Org. Geochem. 107, 33-45. https://doi.org/10.1016/j.orggeochem.2017.02.008

Imran, M., Khan, Z.U.H., Iqbal, J., Shah, N.S., Muzammil, S., Ali, S., Muhammad, N., Aziz, A., Murtaza, B., Naeem, M.A., Amjad, M., Shahid, M., Zakir, A., Rizwan, M., 2020. Potential of siltstone and its composites with biochar and magnetite nanoparticles for the removal of cadmium from contaminated aqueous solutions: Batch and column scale studies, Environ. Pollut. 259, 113938. https://doi.org/10.1016/j.envpol.2020.113938

Jaffé, R., Ding, Y., Niggemann, J., Vähätalo, A. V, Stubbins, A., Spencer, R.G.M., Campbell, J., Dittmar, T., 2013. Global charcoal mobilization from soils via dissolution and riverine transport to the oceans. Science 340, 345-347. https://doi:10.1126/science.1231476

Koide, R. T., Petprakob, K., Peoples, M., 2011. Quantitative analysis of biochar in field soil. Soil Biol. Biochem. 43, 1563-1568. https://doi.org/10.1016/j.soilbio.2011.04.006

Lehmann, J., Liang, B., Solomon, D., Lerotic, M., Luizão, F., Kinyangi, J., Schäfer, T., Wirick, S., Jacobsen, C., 2005. Near-edge X-ray absorption fine structure (NEXAFS) spectroscopy for mapping nano-scale distribution of organic carbon forms in soil: Application to carbon particles. Global. Biogeochem. Cy. 19, https://doi.org/10.1029/2004GB002435

Li, J., Wang, S.-L., Zhang, J., Zheng, L., Chen, D., Wu, Z., Shaheen, S.M., Rinklebe, J., Ok, Y.S., Wang, H., Wu, W., 2020. Coconut-fiber biochar reduced the bioavailability of lead but increased its translocation rate in rice plants: Elucidation of immobilization mechanisms and significance of iron plaque barrier on roots using spectroscopic techniques. J. Hazard. Mater. 389, 122117. https://doi.org/10.1016/j.jhazmat.2020.122117

Li, J., Wang, S.-L., Zheng, L., Chen, D., Wu, Z., Xie, Y., Wu, W., Niazi, N.K., Ok, Y.S., Rinklebe, J., Wang, H., 2019a. Sorption of lead in soil amended with coconut fiber biochar: Geochemical and spectroscopic investigations. Geoderma 
Li, J., Zheng, L., Wang, S.-L., Wu, Z., Wu, W., Niazi, N.K., Shaheen, S.M., Rinklebe, J., Bolan, N., Ok, Y.S. Wang, H., 2019b. Sorption mechanisms of lead on silicon-rich biochar in aqueous solution: Spectroscopic investigation. Sci. Total Environ. 672, 572-582. https://doi.org/10.1016/j.scitotenv.2019.04.003

502

Liang, B., Lehmann, J., Solomon, D., Kinyangi, J., Grossman, J., O’Neill, B., Skjemstad, J. O., Thies, J., Luizão, F. J., Petersen, J., 2006. Black carbon increases cation exchange capacity in soil. Soil. Sci. Soc. Am. J. 70, 1719-1730. https://doi.org/10.2136/sssaj2005.0383

Liang, B., Lehmann, J., Solomon, D., Sohi, S., Thies, J. E., Skjemstad, J. O., Luizão, F. J., Engelhard, M. H., Neves, E. G., Wirick, S., 2008. Stability of biomass-derived black carbon in soils. Geochim. Cosmochim. Ac. 72, 6069-6078. https://doi.org/10.1016/j.gca.2008.09.028

Liu, H., Xu, F., Xie, Y., Wang, C., Zhang, A., Li, L., Xu, H., 2018. Effect of modified coconut shell biochar on availability of heavy metals and biochemical characteristics of soil in multiple heavy metals contaminated soil. Sci. Total Environ. 645, 702-709. https://doi.org/10.1016/j.scitotenv.2018.07.115

Lu, H., Zhang, W., Yang, Y., Huang, X., Wang, S., Qiu, R., 2012. Relative distribution of $\mathrm{Pb}^{2+}$ sorption mechanisms by sludge-derived biochar. Water. Res. 46, 854-862. https://doi.org/10.1016/j.watres.2011.11.058.

Lu, K., Yang, X., Gielen, G., Bolan, N., Ok, Y.S., Niazi, N.K., Xu, S., Yuan, G., Chen, X., Zhang, X., Liu, D., Song, Z., Liu, X., Wang, H., 2017. Effect of bamboo and rice straw biochars on the mobility and redistribution of heavy metals $(\mathrm{Cd}$, $\mathrm{Cu}, \mathrm{Pb}$ and $\mathrm{Zn}$ ) in contaminated soil. J. Environ.Manag. 186, 285-292. https://doi.org/10.1016/j.jenvman.2016.05.068.

Lu, X., Zang, R., Ding, Y., Huang, J., 2018. Partitioning the functional variation of tree seedlings during secondary succession in a tropical lowland rainforest. Ecosphere 9(6), e02305. https://doi.org/10.1002/ecs2.2305

Mia, S., Dijkstra, F.A., Singh, B., 2017. Chapter one - long-term aging of biochar: a molecular understanding with agricultural and environmental implications. Adv. Agron. 141, 1-51. https://doi.org/10.1016/bs.agron.2016.10.001 
Mukherjee, A., Zimmerman, A.R., Cooper, W.T., Hamdan, R., 2014. Physicochemical changes in pyrogenic organic matter (biochar) after 15 months of field aging. Solid Earth 5(2), 693-704. https://doi.org/10.5194/se-5-693-2014

Mumtaz, I., Majeed, Z., Ajab, Z., Ahmad, B., Khurshid, K., Mubashir, M., 2019. Optimized tuning of rosin adduct with maleic anhydride for smart applications in controlled and targeted delivery of urea for higher plant's uptake and growth efficiency. Ind. Crop. Prod. 133, 395-408. https://doi.org/10.1016/j.indcrop.2019.02.036

Ngambia, A., Ifthikar, J., Shahib, I. I., Jawad, A., Shahzad, A., Zhao, M., Wang, J., Chen, Z., Chen, Z., 2019. Adsorptive purification of heavy metal contaminated wastewater with sewage sludge derived carbon-supported $\mathrm{Mg}($ II) composite. Sci. Total Environ. 691, 306-321. https://doi.org/10.1016/j.scitotenv.2019.07.003

Nie, C., Yang, X., Niazi, N.K., Xu, X., Wen, Y., Rinklebe, J., Ok, Y.S., Xu, S., Wang, H., 2018. Impact of sugarcane bagasse-derived biochar on heavy metal availability and microbial activity: A field study. Chemosphere 200, 274-282.https://doi.org/10.1016/j.chemosphere.2018.02.134

Nolan, R.H., Boer, M.M., Collins, L., Resco de Dios, V., Clarke, H., Jenkins, M., Kenny, B., Bradstock, R.A., 2020. Causes and consequences of eastern Australia's 2019-20 season of mega-fires. Global Change Biol. 26(3), 1039-1041. https://doi.org/10.1111/GCB.14987

Pereira, R.C., Arbestain, M.C., Kaal, J., Sueiro, M.V., Sevilla, M., Hindmarsh, J., 2014. Detailed carbon chemistry in charcoals from pre-European Maori gardens of New Zealand as a tool for understanding biochar stability in soils. Eur. J. Soil Sci. 65, 83-95. https://doi.org/10.1111/ejss.12096

Plante, A. F., Fernández, J. M., Leifeld, J., 2009. Application of thermal analysis techniques in soil science. Geoderma 153(1-2), 1-10. https://doi.org/10.1016/j.geoderma.2009.08.016

Qi, F.J., Kuppusamy, S., Naidu, R., Bolan, N.S., Ok, Y.S., Lamb, D., Li, Y.B., Yu, L.B., Semple, K.T., Wang, H.L., 2017. Pyrogenic carbon and its role in contaminant immobilization in soils. Critical Reviews in Environmental Science and Technology 47, 795-876. doi:10.1080/10643389.2017.1328918 
Qin, P., Wang, H., Yang, X., He, L., Müller, K., Shaheen, S.M., Xu, S., Rinklebe, J., Tsang, D.C.W., Ok, Y.S., Bolan, N., Song, Z., Che, L., Xu, X., 2018. Bamboo- and pig-derived biochars reduce leaching losses of dibutyl phthalate, cadmium, and lead from co-contaminated soils. Chemosphere 198, 450-459. https://doi.org/10.1016/j.chemosphere.2018.01.162

Schmidt, M.W.I., Noack, A.G., 2000. Black carbon in soils and sediments: Analysis, distribution, implications, and current challenges. Global Biogeochem. Cy. 14, 777-793. https://doi.org/10.1029/1999GB001208

Ucun, H., Bayhana, Y.K., Kaya, Y., Cakici, A., Algur, O.F., 2003. Biosorption of lead (II) from aqueous solution by cone biomass of Pinus sylvestris. Desalination 154, 233-238. https://doi.org/10.1016/s0011-9164(03)80038-3

Wang, C., Liu, J., Shen, J., Chen, D., Li, Y., Jiang, B., Wu, J., 2018. Effects of biochar amendment on net greenhouse gas emissions and soil fertility in a double rice cropping system: a 4-year field experiment. Agr. Ecosyst. Environ. 262, 83-96. https://doi.org/10.1016/j.agee.2018.04.017

Wang, H., Gao, B., Wang, S., Fang, J., Xue, Y., Kai, Y., 2015. Removal of Pb(II), Cu(II), and Cd(II) from aqueous solutions by biochar derived from $\mathrm{KMnO}_{4}$ treated hickory wood. Bioresour. Technol. 197, 356-362. https://doi.org/10.1016/j.biortech.2015.08.132

Wang, J., Ren, C., Cheng, H., Zou, Y., Bughio, M. A., Li, Q., 2017a. Conversion of rainforest into agroforestry and monoculture plantation in China: consequences for soil phosphorus forms and microbial community. Sci. Total Environ. 595, 769-778. https://doi.org/10.1016/j.scitotenv.2017.04.012

Wang, L., Wang, Y., Ma, F., Tankpa, V., Bai, S., Guo, X., Wang, X., 2019. Mechanisms and reutilization of modified biochar used for removal of heavy metals from wastewater: A review. Sci. Total Environ. 668, 1298-1309. https://doi.org/10.1016/j.scitotenv.2019.03.011

Wang, X., Miao, H., He, W., Shen, H., 2011. Competitive adsorption of $\mathrm{Pb}(\mathrm{II}), \mathrm{Cu}(\mathrm{II})$, and $\mathrm{Cd}(\mathrm{II})$ ions on wheat-residue derived black carbon. J. Chem. Eng. Data 56(3), 444-449. https://doi.org/10.1021/je101079w 
Wei, J., Tu, C., Yuan, G., Zhou, Y., Wang, H., Lu, J., 2020. Limited Cu(II) binding to biochar DOM: Evidence from C K-edge NEXAFS and EEM-PARAFAC combined with two-dimensional correlation analysis. Science of The Total Environment 701, 134919. https://doi.org/10.1016/j.scitotenv.2019.134919

Wu, W., Li, J., Lan, T., Müller, K., Niazi, N. K., Chen, X., Xu, S., Zheng, L., Chu, Y., Li, J., 2017. Unraveling sorption of lead in aqueous solutions by chemically modified biochar derived from coconut fiber: A microscopic and spectroscopic investigation. Sci. Total Environ. 576, 766-774. https://doi.org/10.1016/j.scitotenv.2016.10.163.

Wu, W., Li, J., Niazi, N. K., Müller, K., Chu, Y., Zhang, L., Yuan, G., Lu, K., Song, Z., Wang, H., 2016. Influence of pyrolysis temperature on lead immobilization by chemically modified coconut fiber-derived biochars in aqueous environments. Environ. Sci. Pollut. Res. 23, 22890-22896. https://doi.org/10.1007/s11356-016-7428-0.

Wu, W., Yang, M., Feng, Q., McGrouther, K., Wang, H., Lu, H.H., Chen, Y.X., 2012. Chemical characterization of rice straw-derived biochar for soil amendment. Biomass Bioenergy 47, 268-276. https://doi.org/10.1016/j.biombioe.2012.09.034.

Xia, Y., Yang, T., Zhu, N., Li, D., Chen, Z., Lang, Q., Liu, Z., Jiao, W., 2019. Enhanced adsorption of Pb (II) onto modified hydrochar: modeling and mechanism analysis. Bioresour. Technol. 121593. https://doi.org/10.1016/j.biortech.2019.121593

Xin, X., Qin, W., Jian, Y., Yan, L., Rui, F., Chen, G., Du, B., He, L., 2012. Highly efficient removal of heavy metal ions by amine-functionalized mesoporous $\mathrm{Fe}_{3} \mathrm{O}_{4}$ nanoparticles. Chem. Eng. J. 184, 132-140. https://doi.org/10.1016/j.cej.2012.01.016

Yamada, Y., Suzuki, Y., Yasuda, H., Uchizawa, S., Hirose-Takai, K., Sato, Y., Suenaga, K., Sato, S., 2014. Functionalized graphene sheets coordinating metal cations. Carbon 75, 81-94. https://doi.org/10.1016/j.carbon.2014.03.036

Yang, X., Wan, Y., Zheng, Y., He, F., Yu, Z., Huang, J., Wang, H., Ok, Y.S., Jiang, Y., Gao, B., 2019. Surface functional groups of carbon-based adsorbents and their roles in the removal of heavy metals from aqueous solutions: A critical 

binary oxide-biochar as an adsorbent for removing Cd(II) from aqueous solutions. Chemical Engineering Journal 389, 124465. https://doi.org/10.1016/j.cej.2020.124465

590

591

592

594

Zahedifar, M., 2017. Sequential extraction of zinc in the soils of different land use types as influenced by wheat straw derived biochar. J. Geochem. Explor. 182, 22-31. https://doi.org/10.1016/j.gexplo.2017.08.007

Zhang, J., Shao, J., Jin, Q., Li, Z., Zhang, X., Chen, Y., Zhang, S., Chen, H., 2019. Sludge-based biochar activation to enhance $\mathrm{Pb}$ (II) adsorption. Fuel 252, 101-108. https://doi.org/10.1016/j.fuel.2019.04.096

Zhang, M., Fellowes, J. R., Jiang, X., Wang, W., Chan, B. P. L., Ren, G. , Zhu, J. G., 2010. Degradation of tropical forest in Hainan, China, 1991-2008: conservation implications for hainan gibbon (nomascus hainanus). Biol. Conserv. 6(143), 1397-1404. https://doi.org/10.1016/j.biocon.2010.03.014

Zhang, Q., Yang, Q., Phanlavong, P., Li, Y., Peng, Q., 2017. Highly efficient lead(II) sequestration using size-controllable polydopamine microspheres with superior application capability and rapid capture. Acs Sustain. Chem. Eng. 5, 4161-4170. https://doi.org/10.1021/acssuschemeng.7b00129

Zhang, X., Gao, B., Fang, J., Zou, W., Dong, L., Cao, C., Zhang, J., Li, Y., Wang, H., 2019. Chemically activated hydrochar as an effective adsorbent for volatile organic compounds (VOCs). Chemosphere 218, 680-686. https://doi.org/10.1016/j.chemosphere.2018.11.144

Zhou, T., Wu, L., Luo, Y., Christie, P., 2018. Effects of organic matter fraction and compositional changes on distribution of cadmium and zinc in long-term polluted paddy soils. Environ. Pollut. 232, 1-9. https://doi.org/10.1016/j.envpol.2017.09.081 
609 Fig. 1. The FTIR spectra of SBC samples.

610 Fig. 2. Isotherms of Pb sorption on SBCs.

611 Fig. 3. Total $\mathrm{Pb}$ amounts and $\mathrm{Pb}$ amounts of four fractions on the three $\mathrm{Pb}$-loaded $\mathrm{SBCs}$ prepared under increasing initial

612 concentration of $\mathrm{Pb}$.

613

Fig. 4. Amounts of $\mathrm{Pb}$ in different $\mathrm{Pb}$ fractions on $\mathrm{Pb}$-loaded $\mathrm{SBCs}$ under $\mathrm{Pb}$ concentration of $1000 \mathrm{mg} \mathrm{L} \mathrm{L}^{-1}$.

614 Fig. 5. XPS wide scan spectra of $\mathrm{Pb} 4 \mathrm{f}, \mathrm{C} 1 \mathrm{~s}$ and $\mathrm{O}$ 1s (a), high-resolution spectra of $\mathrm{Pb} 4 \mathrm{f}$ region (b), and high-resolution spectra of $\mathrm{C} 1 \mathrm{~s}$ regions $(\mathrm{c}-\mathrm{h})$ on $\mathrm{SBCs}$ before and after $\mathrm{Pb}$ sorption.

616

617 


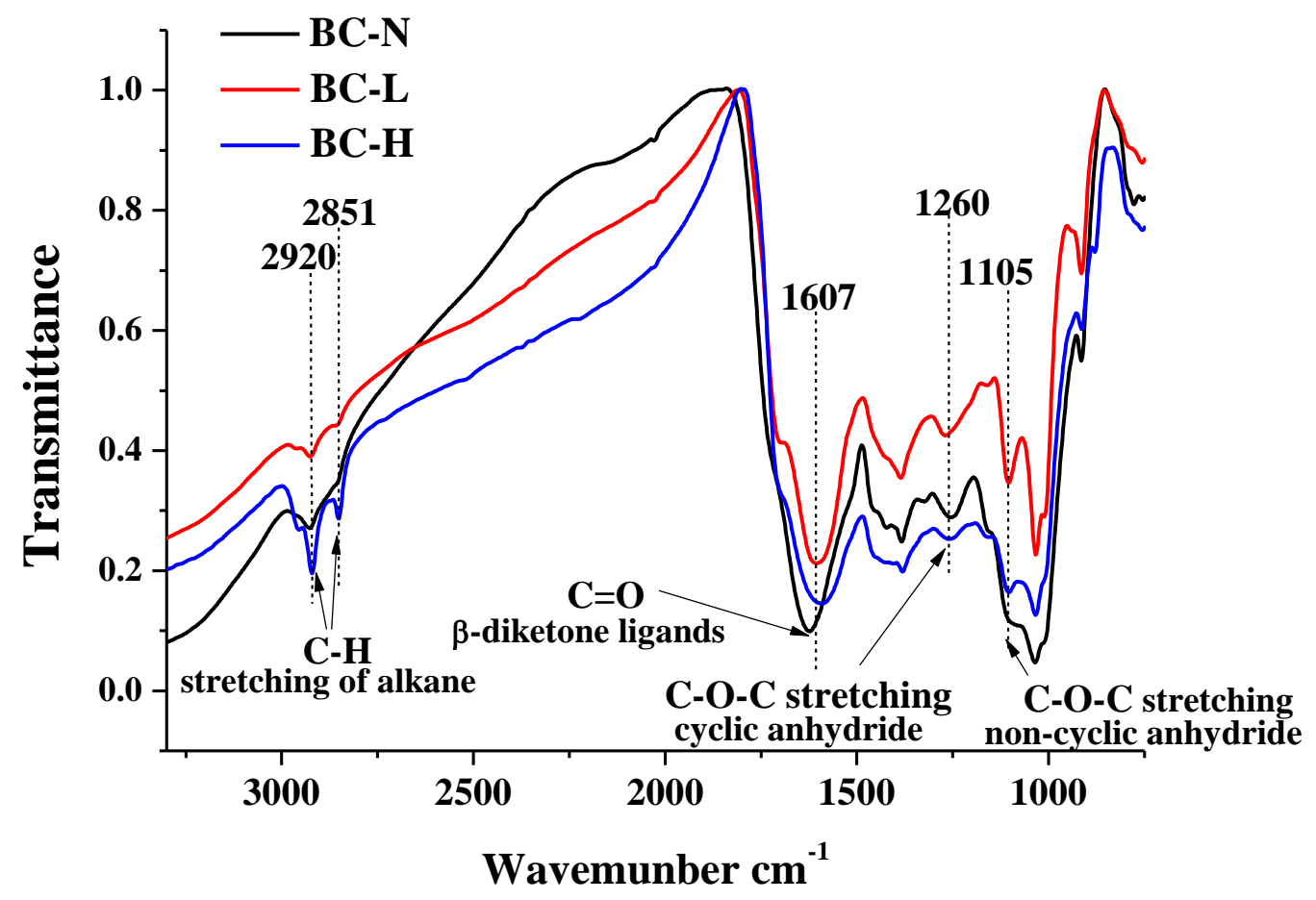

618

619 Fig. 1. The FTIR spectra of SBC samples, the sample ID of BC-N, BC-L and BC-H refer to SBC selected from Soil 1, Soil 2 


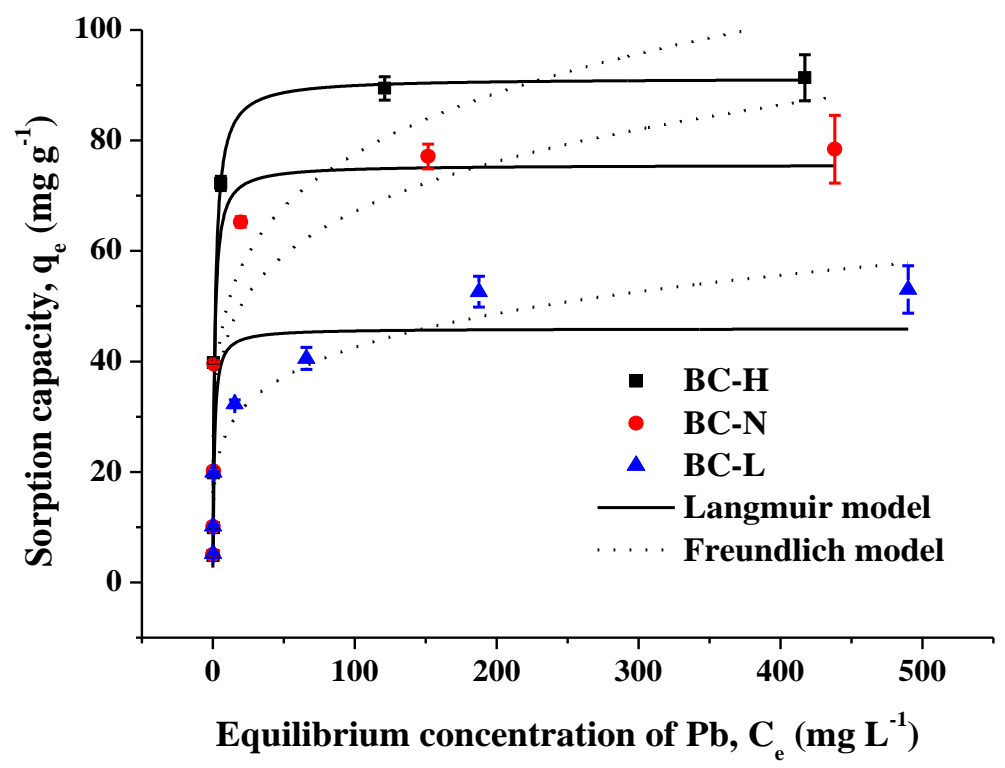

623 Fig. 2. Isotherms of Pb sorption on SBCs.

624 

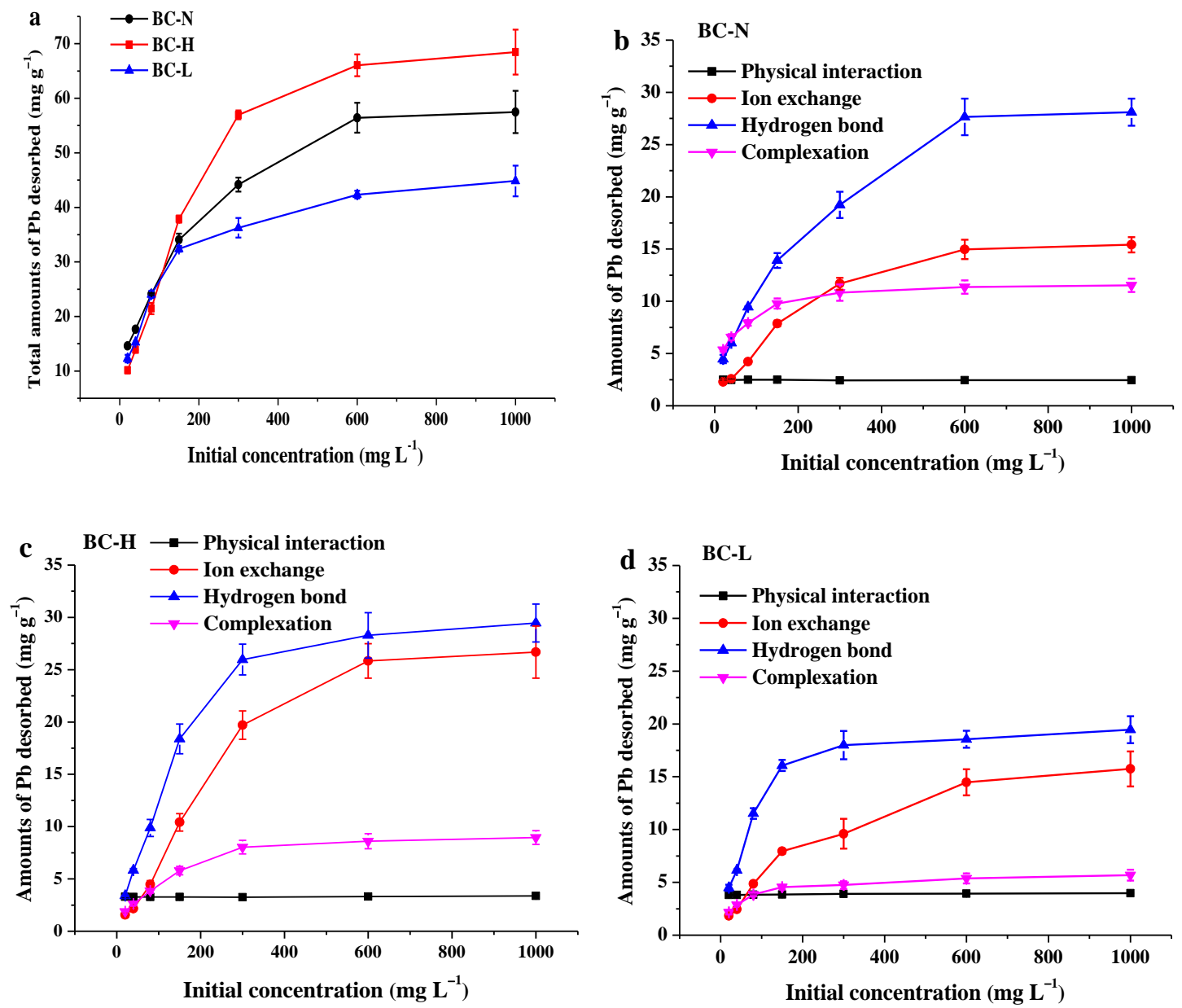

627 Fig. 3. Total $\mathrm{Pb}$ amounts and $\mathrm{Pb}$ amounts of four fractions on the three $\mathrm{Pb}$-loaded SBCs prepared under increasing initial concentration of $\mathrm{Pb}$. 


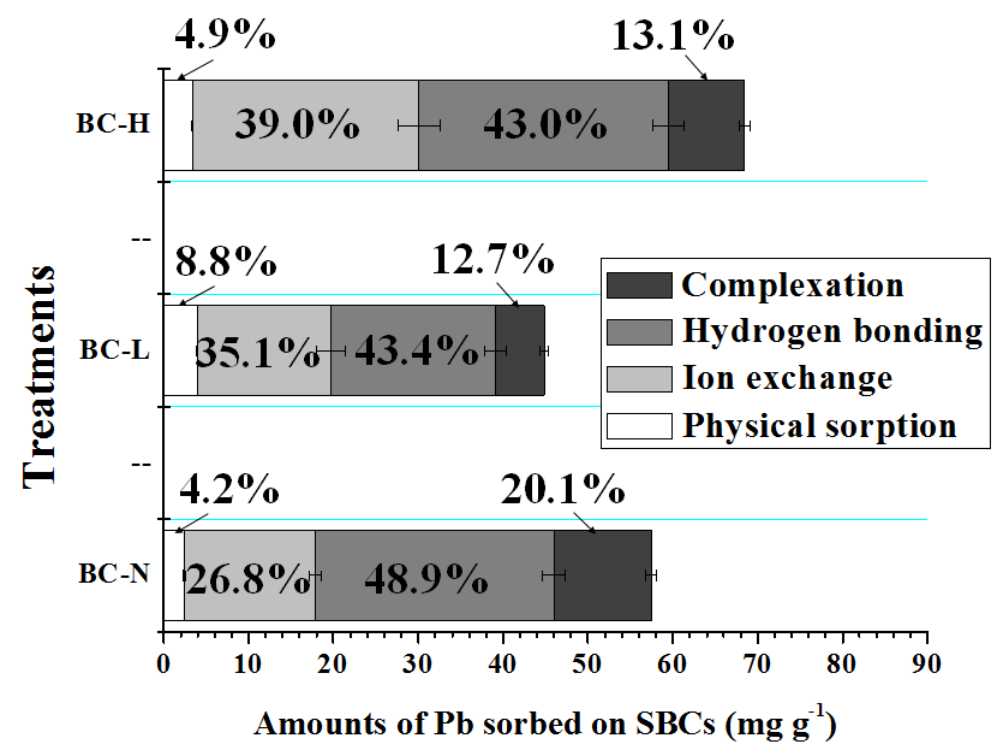

631 Fig. 4. Amounts of $\mathrm{Pb}$ in different $\mathrm{Pb}$ fractions on $\mathrm{Pb}$-loaded $\mathrm{SBCs}$ under $\mathrm{Pb}$ concentration of $1000 \mathrm{mg} \mathrm{L}^{-1}$.

632 

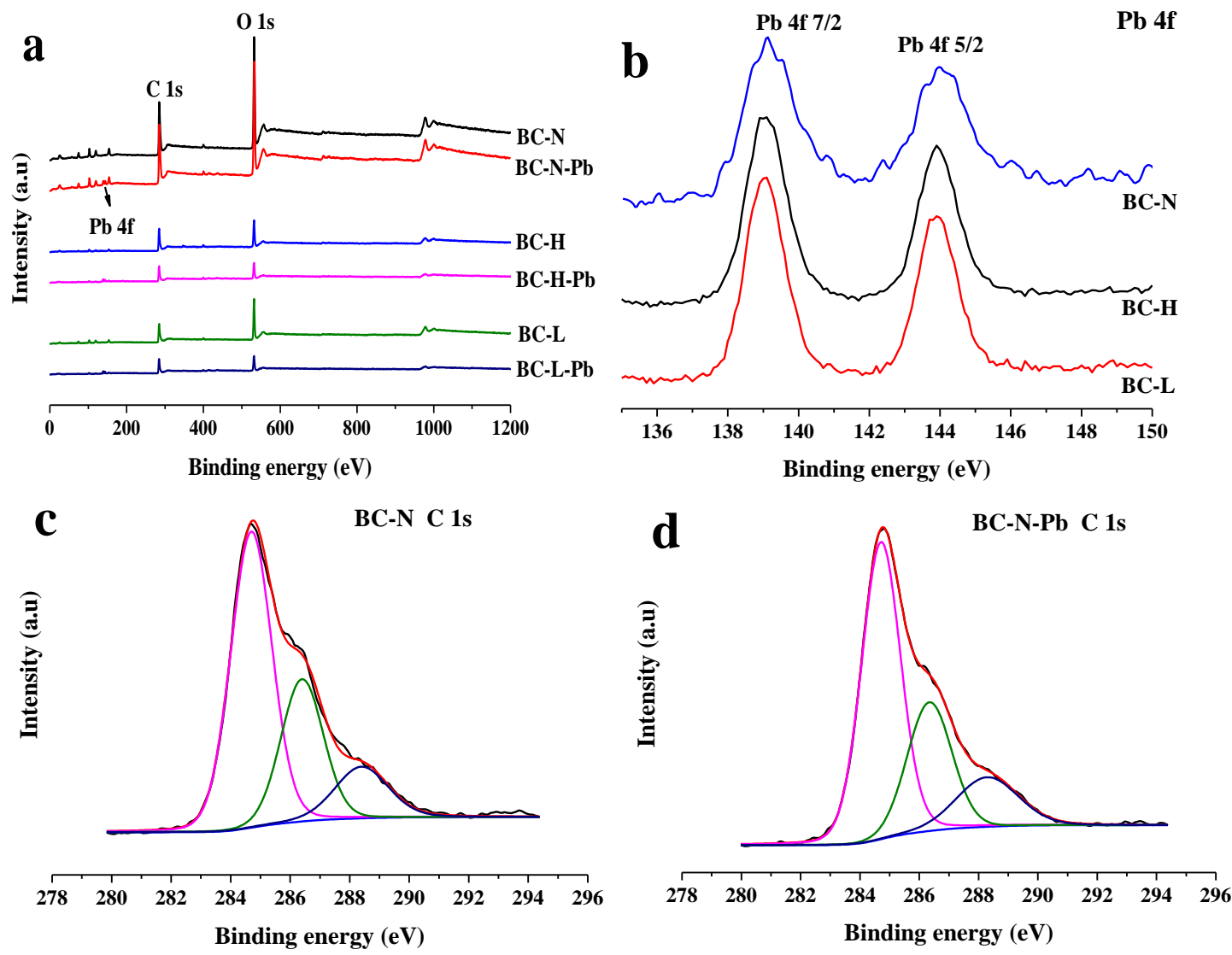

634
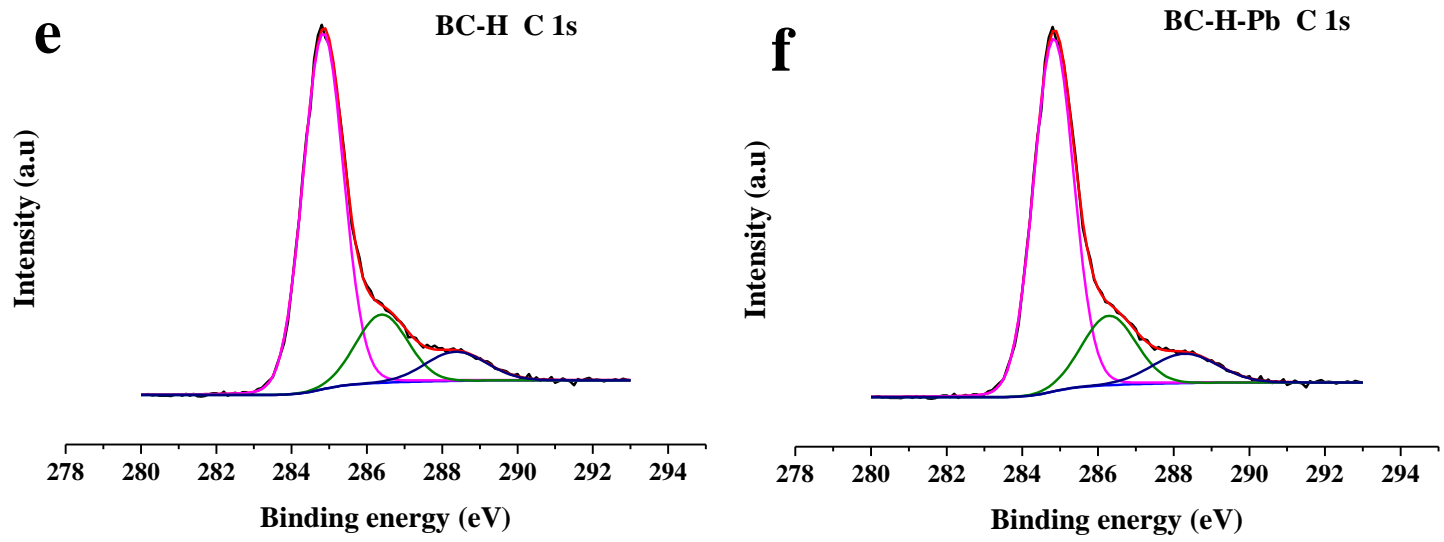

635
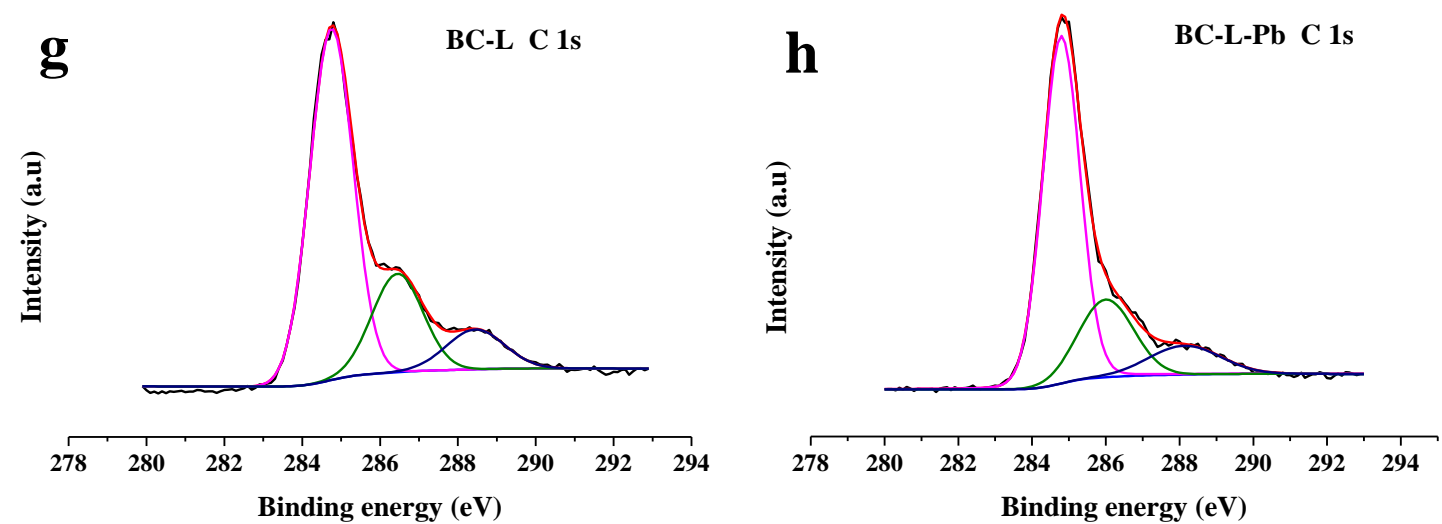

Fig. 5. XPS wide scan spectra of $\mathrm{Pb} 4 \mathrm{f}, \mathrm{C}$ 1s and $\mathrm{O}$ 1s (a), high-resolution spectra of $\mathrm{Pb} 4 \mathrm{f}$ region (b), and high-resolution 
Table 1. Composition and selected properties of SBCs.

\begin{tabular}{|c|c|c|c|c|c|c|c|c|c|c|c|c|}
\hline \multirow{2}{*}{ Sample ID } & \multicolumn{4}{|c|}{ Elemental component $(\%)$} & \multicolumn{3}{|c|}{ Atomic ratio } & \multirow{2}{*}{$\begin{array}{l}\mathrm{n}(\mathrm{RCOOH}) \\
\left(\mathrm{mmol} \mathrm{g}^{-1}\right)\end{array}$} & \multirow{2}{*}{$\begin{array}{l}\mathrm{n}\left(\mathrm{RCOR}^{\prime}\right) \\
\left(\mathrm{mmol} \mathrm{g}^{-1}\right)\end{array}$} & \multirow{2}{*}{$\begin{array}{c}\mathrm{n}(\mathrm{AOH}) \\
\left(\mathrm{mmol} \mathrm{g}^{-1}\right)\end{array}$} & \multirow{2}{*}{$\begin{array}{c}\mathrm{CEC} \\
\left(\mathrm{cmol} \mathrm{kg}{ }^{-1}\right)\end{array}$} & \multirow{2}{*}{$\operatorname{SSA}\left(\mathrm{m}^{2} \mathrm{~g}^{-1}\right)$} \\
\hline & $\mathrm{C}$ & $\mathrm{H}$ & $\mathrm{N}$ & $\mathrm{O}$ & $\mathrm{H} / \mathrm{C}$ & $\mathrm{O} / \mathrm{C}$ & $(\mathrm{O}+\mathrm{N}) / \mathrm{C}$ & & & & & \\
\hline BC-N & 49.1 & 3.61 & 0.73 & 46.5 & 0.88 & 0.71 & 0.72 & $0.53 \pm 0.02$ & $0.70 \pm 0.03$ & $0.34 \pm 0.04$ & $128.0 \pm 24.9$ & $7.51 \pm 1.1$ \\
\hline BC-L & 47.9 & 3.87 & 1.64 & 46.6 & 0.97 & 0.73 & 0.76 & $0.49 \pm 0.01$ & $1.13 \pm 0.19$ & $0.09 \pm 0.01$ & $166.4 \pm 13.4$ & $34.1 \pm 2.7$ \\
\hline BC-H & 45.9 & 3.90 & 2.36 & 47.8 & 1.02 & 0.78 & 0.83 & $0.03 \pm 0.01$ & $0.64 \pm 0.03$ & $1.03 \pm 0.01$ & $227.3 \pm 11.7$ & $20.3 \pm 1.8$ \\
\hline
\end{tabular}

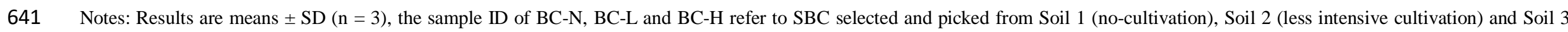

642 (highly intensive cultivation), respectively. While the RCOOH, RCOR', and AOH refer to carboxylic acid, weak acid ester, and phenolic hydroxyl groups, respectively. 
Table 2. Peak positions and relative contents of surface functional groups determined from $\mathrm{C}$ 1s and O 1s XPS spectra for 644 SBCs before and after Pb sorption.

\begin{tabular}{|c|c|c|c|c|c|c|}
\hline \multirow{2}{*}{ Sample ID } & & \multicolumn{3}{|c|}{ Bonds and groups of $\mathrm{C} 1 \mathrm{~s}$} & \multicolumn{2}{|c|}{ Bonds and groups of $\mathrm{O} 1 \mathrm{~s}$} \\
\hline & & $\mathrm{C}-\mathrm{C} / \mathrm{C}=\mathrm{C} / \mathrm{C}-\mathrm{H}$ & $\mathrm{C}-\mathrm{O}$ & $\mathrm{C}=\mathrm{O} / \mathrm{O}-\mathrm{C}=\mathrm{O}$ & $\mathrm{C}=\mathrm{O}$ & $\mathrm{C}-\mathrm{O}$ \\
\hline \multirow[t]{2}{*}{ BC-N } & Beam energy $(\mathrm{eV})$ & 284.7 & 286.4 & 288.4 & 531.9 & 532.8 \\
\hline & Atomic percentage $(\%)$ & 58.2 & 28.3 & 13.6 & 59.7 & 40.3 \\
\hline \multirow[t]{2}{*}{ BC-N-Pb } & Beam energy $(\mathrm{eV})$ & 284.7 & 286.3 & 288.3 & 532 & 532.8 \\
\hline & Atomic percentage (\%) & 57.4 & 27.5 & 15.1 & 62.3 & 37.7 \\
\hline \multirow[t]{2}{*}{ BC-L } & Beam energy (eV) & 284.7 & 286.4 & 288.4 & 532 & 532.9 \\
\hline & Atomic percentage $(\%)$ & 67.5 & 22.2 & 10.3 & 61.8 & 38.2 \\
\hline \multirow[t]{2}{*}{$\mathrm{BC}-\mathrm{L}-\mathrm{Pb}$} & Beam energy $(\mathrm{eV})$ & 284.7 & 286.3 & 288.3 & 531.8 & 532.8 \\
\hline & Atomic percentage $(\%)$ & 67.7 & 21.8 & 10.5 & 62.4 & 37.6 \\
\hline \multirow[t]{2}{*}{$\mathrm{BC}-\mathrm{H}$} & Beam energy $(\mathrm{eV})$ & 284.8 & 286.3 & 288.3 & 531.9 & 532.7 \\
\hline & Atomic percentage $(\%)$ & 73.2 & 19.3 & 7.5 & 64.5 & 35.5 \\
\hline \multirow[t]{2}{*}{$\mathrm{BC}-\mathrm{H}-\mathrm{Pb}$} & Beam energy (eV) & 284.8 & 286.3 & 288.3 & 531.9 & 533.2 \\
\hline & Atomic percentage $(\%)$ & 72 & 18.5 & 9.5 & 77.4 & 22.6 \\
\hline
\end{tabular}

645

646 
647

648

649

650

651

652

653

654

655

656

657

658

659

660

661

662

663

664

665

666

667

668

669

670

Supplementary Material:

\title{
Sorption mechanisms of lead on soil-derived black carbon formed under varying cultivation systems
}

\author{
Qingjie Zhao ${ }^{\text {a,1 }}$, Jianhong Li ${ }^{\text {a,b,1, Binoy Sarkar }}{ }^{\text {c }}$, Weidong Wu ${ }^{\text {a }}$, Boling Li a ${ }^{\text {, Ruichun Liu }}{ }^{\text {d }}$, Mohsin \\ $\operatorname{Nawaz}^{\text {e }}$, Muhammad Zia-ur-Rehman ${ }^{\text {f }}$, Hailong Wang ${ }^{\text {b,g,**, Zhipeng Wu }}{ }^{\text {a,* }}$ \\ ${ }^{a}$ College of Tropical Crops, Hainan University, Haikou 570228, China \\ ${ }^{\mathrm{b}}$ Biochar Engineering Technology Research Center of Guangdong Province, School of Environmental and \\ Chemical Engineering, Foshan University, Foshan 528000, China \\ ${ }^{\mathrm{c}}$ Lancaster Environment Centre, Lancaster University, Lancaster, LA1 4YQ, United Kingdom \\ ${ }^{\mathrm{d}}$ Flood Control and Drought Relief Office of Hangjin County, Ordos 017400, China \\ e Key Laboratory of Genetics and Germplasm Innovation of Tropical Special Forest Trees and Ornamental \\ Plants, Ministry of Education, College of Forestry, Hainan University, Haikou 570228, China \\ ${ }^{\mathrm{f}}$ Institute of Soil and Environmental Sciences, University of Agriculture, Faisalabad, 38040, Pakistan \\ g Key Laboratory of Soil Contamination Bioremediation of Zhejiang Province, Zhejiang A\&F University, \\ Hangzhou 311300, China
}

${ }^{*}$ Corresponding author.

** Correspondence to: H. Wang, School of Environmental and Chemical Engineering, Foshan University, Foshan 528000, China

E-mail addresses: hailong.wang@fosu.edu.cn (H. Wang), peter@hainanu.edu.cn (Z.Wu).

${ }^{1}$ Qingjie Zhao and Jianhong Li contributed to the work equally and should be considered co-first authors. 
672 The pseudo-first-order (Eq. 1) and pseudo-second-order (Eq. 2) models used in this study:

$673 \ln \left(\mathrm{q}_{\mathrm{e}}-\mathrm{q}_{\mathrm{t}}\right)=\ln \mathrm{q}_{\mathrm{e}}-\mathrm{k}_{1} \mathrm{t}$ 1

$674 \mathrm{t} / \mathrm{q}_{\mathrm{t}}=1 / \mathrm{k}_{2} \mathrm{q}_{\mathrm{e}}^{2}+1 / \mathrm{q}_{\mathrm{e}}$ 2

675 where, $\mathrm{k}_{1}\left(\mathrm{~h}^{-1}\right)$ and $\mathrm{k}_{2}\left(\mathrm{~h}^{-1} \cdot\left(\mathrm{g} \mathrm{mg}^{-1}\right)\right)$ are the rate constants of the pseudo first-order and pseudo-second order

676 models, respectively. While, $\mathrm{q}_{\mathrm{e}}$ and $\mathrm{q}_{\mathrm{t}}$ is the amount of $\mathrm{Pb}$ sorbed by $\mathrm{SBC}$ at equilibrium and at time $(\mathrm{t})$ in $\mathrm{mg} \mathrm{g}^{-1}$,

677 respectively.

678

The Langmuir (Eq. 3) and Freundlich (Eq. 4) models used in this study:

679

$\mathrm{q}_{\mathrm{e}}=\mathrm{q}_{\max } \mathrm{K}_{\mathrm{L}} \mathrm{C}_{\mathrm{e}} /\left(1+\mathrm{K}_{\mathrm{L}} \mathrm{C}_{\mathrm{e}}\right)$

$680 \quad \mathrm{q}_{\mathrm{e}}=\mathrm{K}_{\mathrm{f}} \mathrm{C}_{\mathrm{e}}^{1 / \mathrm{n}}$

681 where, $\mathrm{q}_{\mathrm{e}}\left(\mathrm{mg} \mathrm{g}^{-1}\right)$ and $\mathrm{C}_{\mathrm{e}}\left(\mathrm{mg} \mathrm{L}^{-1}\right)$ are the amounts of $\mathrm{Pb}$ sorbed by $\mathrm{SBC}$ for a given initial $\mathrm{Pb}$ concentration, and the concentration of $\mathrm{Pb}$ in solution at equilibrium, respectively. While, $\mathrm{q}_{\mathrm{m}}\left(\mathrm{mg} \mathrm{g}^{-1}\right)$ is the maximum amount of $\mathrm{Pb}$ adsorbed at equilibrium, $\mathrm{K}_{\mathrm{L}}\left(\mathrm{L} \mathrm{mg}^{-1}\right)$ is the Langmuir constant; $\mathrm{n}$ and $\mathrm{K}_{\mathrm{f}}\left(\left(\mathrm{mg} \mathrm{g}^{-1}\right) \cdot\left(\mathrm{mg} \mathrm{L}^{-1}\right)^{-\mathrm{n}}\right)$ are equilibrium constants relating to sorption intensity and sorption capacity of the Freundlich model, respectively. 
Table S1. Parameters of pseudo-first-order and pseudo-second-order kinetic models for Pb sorption on SBCs.

\begin{tabular}{ccccccc}
\hline & \multicolumn{3}{c}{ Pseudo-first-order } & \multicolumn{3}{c}{ Pseudo-second-order } \\
\cline { 2 - 6 } Sample ID & $\mathrm{q}_{\mathrm{e}}\left(\mathrm{mg} \mathrm{g}^{-1}\right)$ & $\mathrm{k}_{1}\left(1 \mathrm{~h}^{-1}\right)$ & $\mathrm{r}^{2}$ & $\mathrm{q}_{\mathrm{e}}\left(\mathrm{mg} \mathrm{g}^{-1}\right)$ & $\mathrm{k}_{2}\left({\mathrm{~g} \mathrm{mg} \mathrm{m}^{-}}^{-}\right.$ & $\mathrm{r}^{2}$ \\
& 31.18 & 7.22 & 0.795 & 32.92 & 0.356 & 0.998 \\
\hline BC-N & 27.33 & 0.89 & 0.787 & 30.66 & 0.034 & 0.979 \\
BC-L & 49.11 & 13.19 & 0.992 & 50.63 & 0.592 & 0.999 \\
BC-H & & & & & & \\
\hline
\end{tabular}

Table S2. Parameters of Langmuir and Freundlich isotherm models for Pb sorption on SBCs.

\begin{tabular}{|c|c|c|c|c|c|c|}
\hline \multirow{2}{*}{ Sample ID } & \multicolumn{3}{|c|}{ Langmuir } & \multicolumn{3}{|c|}{ Freundlich } \\
\hline & $\mathrm{q}_{m}\left(\mathrm{mg} \mathrm{g}^{-1}\right)$ & $\mathrm{K}_{L}\left(\mathrm{~L} \mathrm{mg}^{-1}\right)$ & $r^{2}$ & $\mathrm{~K}_{f}\left(\mathrm{mg}^{\left(1^{-} \mathrm{n}\right)} \mathrm{L}^{\mathrm{n}} \mathrm{g}^{-1}\right)$ & $\mathrm{n}$ & $r^{2}$ \\
\hline $\mathrm{BC}-\mathrm{N}$ & 75.6 & 0.916 & 0.981 & 29.11 & 0.182 & 0.847 \\
\hline BC-L & 46.0 & 1.064 & 0.854 & 17.53 & 0.193 & 0.925 \\
\hline BC-H & 91.3 & 0.675 & 0.920 & 32.13 & 0.191 & 0.728 \\
\hline
\end{tabular}

688 
690 Table S3. Sorption capacities of different biochars for removing $\mathrm{Pb}$ from aqueous solution at $\mathrm{pH}$ of 5.0.

\begin{tabular}{cccc}
\hline Type of biochars & Metal ion & $\mathrm{Q}_{\mathrm{m}}\left(\mathrm{mg} \mathrm{g}^{-1}\right)$ & References \\
\hline Oak bark char & $\mathrm{Pb}^{2+}$ & 13.1 & Mohan et al. 2007 \\
Pomelo peel biochar & $\mathrm{Pb}^{2+}$ & 88.7 & Zhao et al., 2018 \\
Coconut-fiber biochar & $\mathrm{Pb}^{2+}$ & 79.4 & Li et al., 2019 \\
Raw sugarcane bagasse biochar & $\mathrm{Pb}^{2+}$ & 81.9 & Inyang et al., 2011 \\
Corn stover biochar & $\mathrm{Pb}^{2+}$ & 63.3 & Li et al., 2018 \\
Digested sugar beet biochar & $\mathrm{Pb}^{2+}$ & 51.4 & Inyang et al., 2012 \\
\hline
\end{tabular}

691

692 Table S4. The parameters $\left(\mathrm{r}^{2}\right)$ of Langmuir model for different $\mathrm{Pb}$ fractions on $\mathrm{Pb}$-loaded SBCs under increasing 693 initial $\mathrm{Pb}$ concentrations.

\begin{tabular}{cccccc}
\hline Sample ID & Physical interaction & Ion exchange & Hydrogen bond & Complexation & Total amount \\
\hline BC-N & - & 0.984 & 0.983 & 0.971 & 0.969 \\
BC-L & - & 0.986 & 0.968 & 0.979 & 0.987 \\
BC-H & - & 0.966 & 0.973 & 0.984 & 0.983 \\
\hline
\end{tabular}


Table S5. Amounts of $\mathrm{Pb}$ in different fractions on Pb-loaded SBCs (prepared under Pb concentration of $1000 \mathrm{mg} \mathrm{L}^{-1}$ ).

\begin{tabular}{ccccccc}
\hline & \multicolumn{4}{c}{ Amount of Pb in different fractions $\left(\mathrm{mg} \mathrm{g}^{-1}\right)$} & & Amount of sorbed Pb \\
\cline { 2 - 6 } Sample ID & $\begin{array}{c}\text { Physical } \\
\text { adsorption }\end{array}$ & Ion exchange & Hydrogen bonding & complexation & $\begin{array}{c}\text { Total amount of } \\
\text { in a stable form in } \\
\text { desorption }\end{array}$ & \begin{tabular}{c} 
soil $\left(\mathrm{mg} \mathrm{kg}^{-1}\right)^{\alpha}$ \\
\hline BC-N
\end{tabular} \\
\cline { 2 - 6 } & 2.44 & 15.41 & 28.10 & 11.53 & 57.48 & 19.0 \\
BC-L & 3.97 & 15.74 & 19.45 & 5.68 & 44.84 & 18.7 \\
BC-H & 3.37 & 26.68 & 29.46 & 8.95 & 68.46 & 21.1 \\
\hline
\end{tabular}

$696{ }^{\alpha}$ The amount of sorbed $\mathrm{Pb}$ in a stable form in soil (attribute to $\mathrm{SBC}$ sorption) was calculated by the equation: $\mathrm{Q}_{\mathrm{sta}}=\mathrm{M}_{\mathrm{SBC}} \times \mathrm{Q}_{\mathrm{com}}$, where $\mathrm{Q}_{\mathrm{sta}}$, $\mathrm{M}_{\mathrm{SBC}}$, and $\mathrm{Q}_{\mathrm{com}}$ refer to the

697 amount of stable $\mathrm{Pb}$ (in $\mathrm{mg} \mathrm{kg}^{-1}$ ), the content of $\mathrm{SBC}$ in soil (in $\mathrm{g} \mathrm{kg}^{-1}$ ), and amount of $\mathrm{Pb}$ in complexation fraction (in mg g $\mathrm{g}^{-1}$ ), respectively. 
Table S6. Equivalents of adsorbed $\mathrm{Pb}$ by released cations from $\mathrm{Pb}$-loaded SBCs.

\begin{tabular}{ccccc}
\hline Sample ID & $\mathrm{K}+(\mathrm{mg} g-1)$ & $\mathrm{Na}+(\mathrm{mg} \mathrm{g}-1)$ & $\mathrm{Ca} 2+(\mathrm{mg} \mathrm{g}-1)$ & $\mathrm{Mg} 2+(\mathrm{mg}$ g-1) \\
\hline BC-N & $1.32 \pm 0.03$ & $4.00 \pm 0.96$ & $7.12 \pm 0.88$ & $0.83 \pm 0.01$ \\
BC-L & $0.97 \pm 0.12$ & $2.03 \pm 0.28$ & $12.3 \pm 1.78$ & $0.33 \pm 0.03$ \\
BC-H & $0.98 \pm 0.02$ & $2.69 \pm 0.44$ & $14.5 \pm 3.51$ & $0.47 \pm 0.01$ \\
\hline
\end{tabular}

699
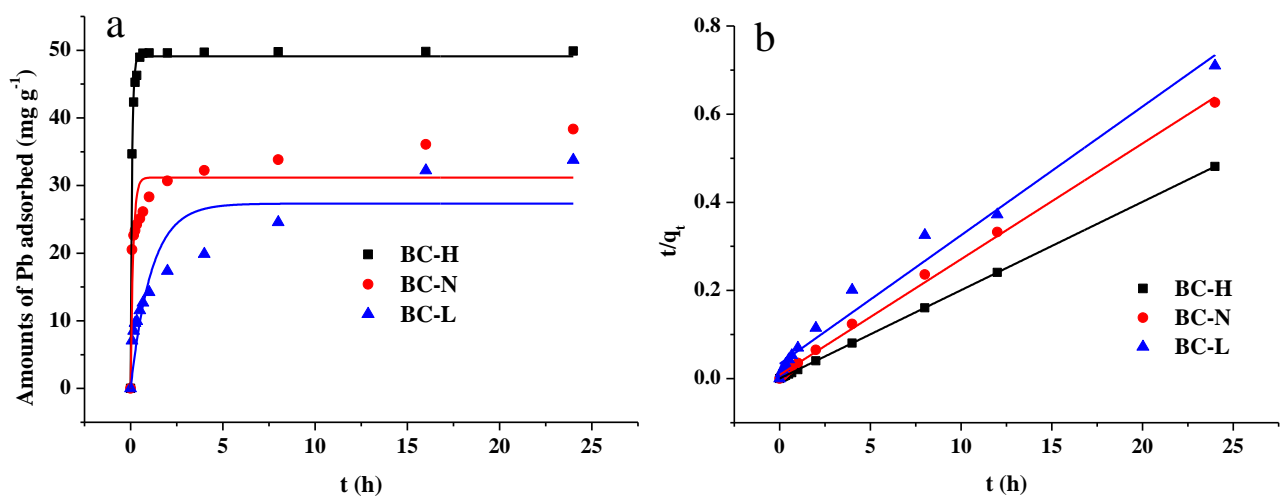

700

701 Fig. S1. Kinetics of Pb sorption on SBCs, a) pseudo-first-order kinetic model; b) pseudo-second-order kinetic 702 model. 

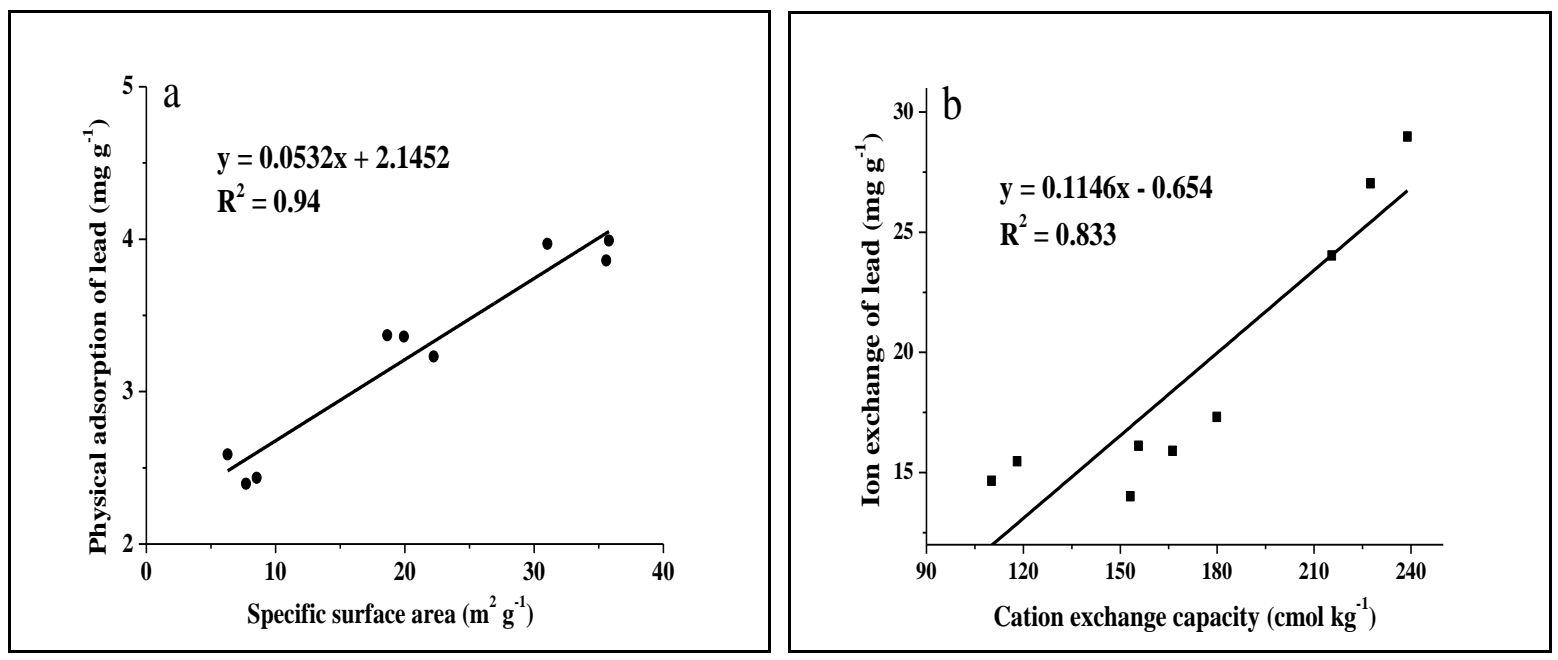

705
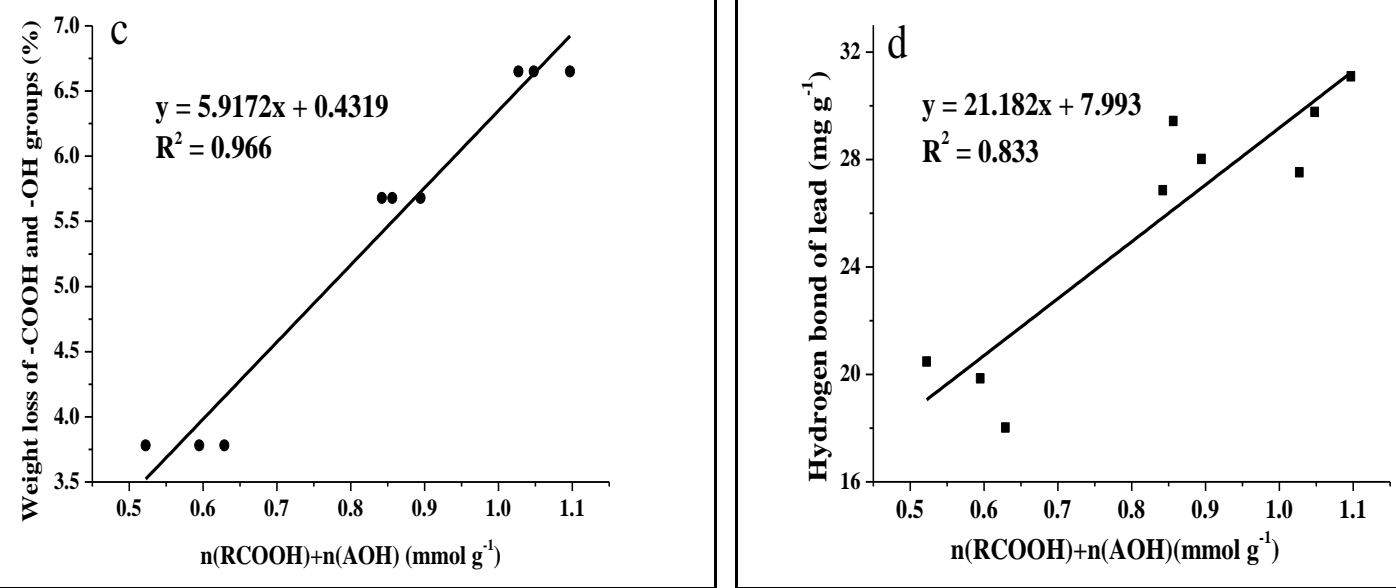

Fig. S2. Correlations between the amount of $\mathrm{Pb}$ in different fractions on $\mathrm{Pb}$-loaded $\mathrm{SBC}$ and specific properties of SBCs. a) physical adsorption fraction vs. specific surface area; b) ion exchange fraction vs. CEC; c) weight loss of $-\mathrm{COOH}$ and $-\mathrm{OH}$ groups on $\mathrm{SBCs}$ vs. the sum content of $\mathrm{RCOOH}$ and $\mathrm{AOH}$ functional groups on SBCs; and d) hydrogen bonding fraction vs. the sum content of $\mathrm{RCOOH}$ and $\mathrm{AOH}$ functional groups on SBCs. 

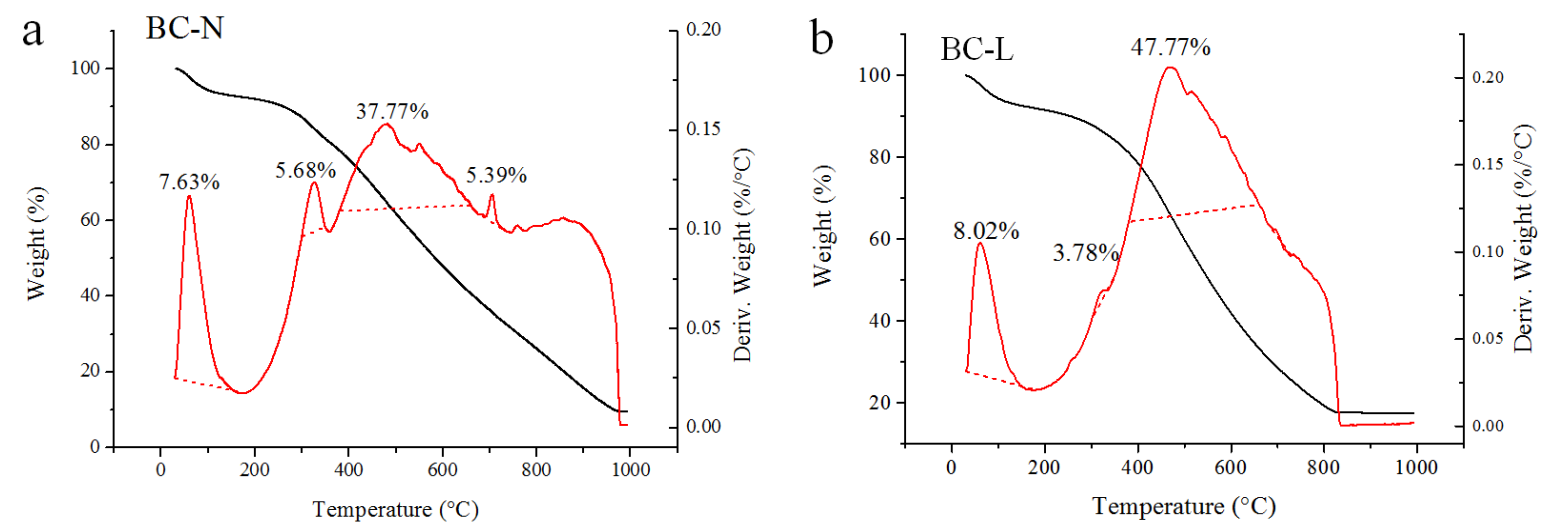

711

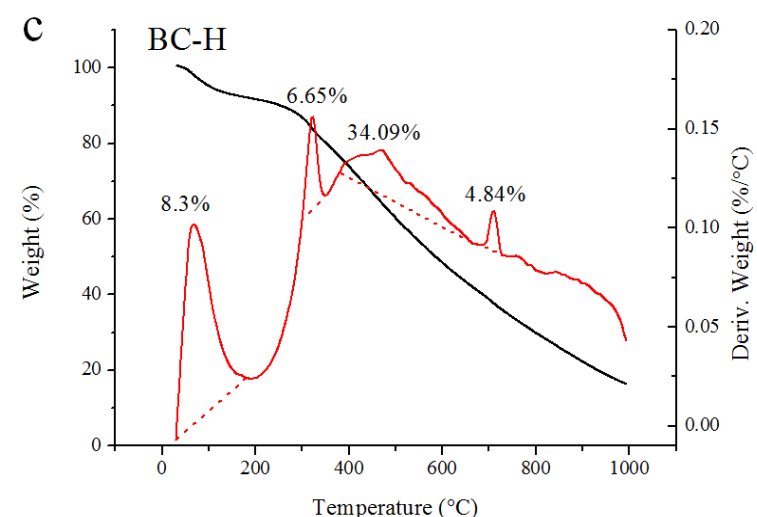

712

713 Fig. S3. Thermogravimetric (TG, black line) and differential thermogravimetric (DTG, red line) curves of SBC samples: a)

714 BC-N, b) BC-L, and c) BC-H.

715 
717 Inyang, M., Gao, B., Ding, W., Pullammanappallil, P., Zimmerman, A.R., Cao, X.D., 2011. Enhanced lead sorption by biochar derived from anaerobically digested sugarcane bagasse. Sep. Sci. Technol. 46(12), 1950-1956. https://doi.org/10.1080/01496395.2011.584604

Inyang, M., Gao, B., Yao, Y., Xue, Y.W., Zimmerman, A.R., Pullammanappallil, P., Cao, X.D., 2012. Removal of heavy metals from aqueous solution by biochars derived from anaerobically digested biomass. Bioresour. Technol. 110, 50-56. https://doi.org/10.1016/j.biortech.2012.01.072

Li, C., Zhang, L., Gao, Y., Li, A., 2018. Facile synthesis of nano ZnO/ZnS modified biochar by directly pyrolyzing of zinc contaminated corn stover for $\mathrm{Pb}(\mathrm{II}), \mathrm{Cu}(\mathrm{II})$ and $\mathrm{Cr}(\mathrm{VI})$ removals. Waste. Manage. 79, 525-637. https://doi.org/10.1016/j.wasman.2018.08.035

Li, J., Zheng, L., Wang, S.-L., Wu, Z., Wu, W., Niazi, N.K., Shaheen, S.M., Rinklebe, J., Bolan, N., Ok, Y.S.,

Zhao, T., Yao, Y., Li, D., Wu, F., Zhang, C., Gao, B., 2018. Facile low-temperature one-step synthesis of pomelo peel biochar under air atmosphere and its adsorption behaviors for $\mathrm{Ag}(\mathrm{I})$ and $\mathrm{Pb}(\mathrm{II})$. Sci. Total Environ. 604-601, 73-79. https://doi.org/10.1016/j.scitotenv.2018.05.251 